\title{
LEGAL AND COMMERCIAL MODELS FOR PORE-SPACE ACCESS AND USE FOR GEOLOGIC $\mathrm{CO}_{2}$ SEQUESTRATION
}

\author{
R. Lee Gresham ${ }^{\dagger}$ and Owen L. Anderson*
}

The ever-increasing interest in developing commercial-scale geologic carbon dioxide $\left(\mathrm{CO}_{2}\right)$ sequestration (GCS) has sparked an intense debate about the ownership and commercial use of pore space. To geologically sequester $\mathrm{CO}_{2}$ in deep saline formations, the gas is compressed to a supercritical fluid and injected approximately a kilometer or deeper into the microscopic pore space in deep subsurface rock matrixes. Injected $\mathrm{CO}_{2}$ flows through and fills the pore spaces in permeable layers of the rock matrix, while its upward migration is prevented by less permeable rock layers. Depending on the formation geology and the depth, porosity, and permeability of the injection zone, sequestered $\mathrm{CO}_{2}$ from a single project could potentially spread over hundreds to thousands of square kilometers, ${ }^{1}$ and subsurface pressure effects could be felt over an even greater area. Carbonaceous shales, such as the Marcellus, are also a possible target for geologic $\mathrm{CO}_{2}$ sequestration. Because carbon adsorbs carbon dioxide at a greater rate than methane, $\mathrm{CO}_{2}$ injected into the formation for GCS could theoretically be used to recover additional natural gas in a process analogous to enhanced coal bed methane recovery, though the practical value of this technique is not yet known. ${ }^{2}$ Scientists believe that adsorption would allow sequestration at shallower depths than absorption in deep saline formations, which must be at least 800 meters (2,600 feet) below the surface to maintain liquid $\mathrm{CO}_{2}$ in a supercritical state.

Current resource estimates for sequestration in deep saline formations do not account for reduced capacity due to conflicting uses of pore space, such as

\footnotetext{
$\dagger \quad$ Lee Gresham is a Post-Doctoral Research Fellow with the Carbon Capture \& Sequestration Regulatory Project, Department of Engineering \& Public Policy, Carnegie Mellon University.

* Owen L. Anderson is the Eugene Kuntz Chair in Oil, Gas and Natural Resources, The University of Oklahoma College of Law.

1. See Karsten Pruess et al., Numerical Modeling of Aquifer Disposal of CO2, 8 SPE J. 49 (2003); Sean T. Brennan \& Robert C. Burruss, Specific Storage Volumes: A Useful Tool or CO2 Storage Capacity Assessment, 15 NAT. RESOURCES RES. 165, 182 (2006); R. Lee Gresham et al., Implications of Compensating Property Owners for Geological CO2 Sequestration, 44 ENVTL. SCI. TECH. 2897, 2900 (2010).

2. LaWrence H. Wickstrom et al., Ohio Dep'T of Natural Res., GeOlogical Assessment of the Burger Power Plant and Surrounding Vicinity for Potential InJection of Carbon DIOXIDE (2008).
} 
enhanced oil recovery operations, shale gas production, and natural gas storage. Therefore, the commercial viability of $\mathrm{CO}_{2}$ sequestration may, in large part, depend on how issues related to property rights and competing uses of the subsurface are resolved. ${ }^{3}$ Prior to injecting $\mathrm{CO}_{2}$ into the subsurface for permanent geologic sequestration, the injector must either own the pore space, have permission from the owner, or have statutory or common-law right to use the pore space that avoids potential liability or exposure to trespass and nuisance claims. Consequently, before a geologic $\mathrm{CO}_{2}$ sequestration field can be developed, the project developer will have to acquire the authorization to access and use pore space to avoid liability for subsurface trespass and nuisance. If a GCS project development receives authorization from the state or federal government to use pore space and the authorization shields the developer from trespass to any degree, then takings law will certainly be implicated as well. This article considers the legal and commercial models for securing the rights to use geologic pore space in an effort to sequester billions of metric tons of $\mathrm{CO}_{2}$ deep underground to mitigate climate change.

We recommend that the federal and state governments should codify a formal process for permitting the access and use of pore space for GCS on federal and privately-owned lands, whereby the holder of a valid permit is exposed to compensable trespass and nuisance liability only when actual and substantial damages are caused by the injection and migration of $\mathrm{CO}_{2}$. However, we recognize that to assure the long-term integrity of carbon sequestration reservoirs, it may be necessary to acquire a more robust property interest, such as a sequestration easement, throughout the entire reservoir. Therefore, the permitting framework should include a backstop such as eminent domain legislation similar to the laws that facilitate the underground storage of natural gas. Such a framework should facilitate the rapid development of commercial-scale GCS projects by both standardizing procedures for acquiring the authorization to use pore space as well as constraining acquisition costs.

3. See generally Elizabeth J. Wilson \& Mark A. de Figueiredo, Geologic Carbon Dioxide Sequestration: An Analysis of Subsurface Property Law, 36 EnVTL. L. InST. 10114 (2006); Owen L. Anderson, Geologic CO2 Sequestration: Who Owns the Pore Space?, 9 WYO.L. REV. 97 (2009) [hereinafter Anderson I]; Owen L. Anderson, Lord Coke, the Restatement, and Modern Subsurface Trespass Law, 57th ANN. INST. ON MIN. L. 22 (2010), reprinted, _ TEX OIL \& GAS L.J.__ (2011) [hereinafter Anderson II]; Alexandra B. Klass \& Elizabeth J. Wilson, Climate Change, Carbon Sequestration, and Property Rights, 2010 U. ILL. L. REV. 363 (2010). 


\section{The Intersection Between Subsurface Property Rights, Geologic $\mathrm{CO}_{2}$ SEQuestration, AND COMPETING USES OF THE SubSuRfaCe}

For GCS to enable the continued use of fossil fuels and simultaneous deep emission reductions, it must be widely deployed. To do this, the technology must be integrated into a larger commercial, legal, and regulatory scheme. Of key import are: (1) the amount of $\mathrm{CO}_{2}$ to be injected-a $1 \mathrm{GW}$ coal-fired power plant typically produces roughly 6 to 8 million metric tons of $\mathrm{CO}_{2}{ }^{4}$ annually; (2) the areal footprint over which the injected $\mathrm{CO}_{2}$ will migrate; and (3) the need for injected $\mathrm{CO}_{2}$ to remain in the subsurface hundreds to thousands of years, effectively occupying the subsurface pore space in perpetuity. Because of the potentially large size of geologic sequestration projects - the injected $\mathrm{CO}_{2}$ could migrate over hundreds, perhaps thousands, of square kilometers ${ }^{5}$ - other economic uses of the subsurface, such as hydrocarbon production, natural gas storage, fluid waste disposal, and groundwater recovery and storage, could coexist with subsurface $\mathrm{CO}_{2}$ injection. ${ }^{6}$ Throughout the United States, subsurface activities vary extensively, as do the depths at which these industrial and commercial enterprises are carried out. Many proposed and future $\mathrm{CO}_{2}$ sequestration projects will overlap and some will be part of these other subsurface enterprises, especially enhanced hydrocarbon recovery ${ }^{7}$ projects that inject $\mathrm{CO}_{2}$ to repressurize production fields. ${ }^{8}$ State legislatures, particularly in oil and

4. Corresponds to $1 \mathrm{~kg} / \mathrm{kWh}$ captured at $60 \%$ and $90 \%$ capture efficiency, respectively.

5. Gresham et al., supra note 1, at 2900.

6. See U.S. Dep't of the Interior, Report to Congress: Framework for GeOlogical CARbon SEQUeSTRATION ON PUBLIC LAND 1 (June 3, 2009) (“[C]arbon sequestration may potentially conflict with other land uses including existing and future mines, oil and gas fields, coal resources, geothermal fields, and drinking water sources.").

7. In "enhanced" or "secondary" recovery operations, oil and gas producers inject fluids into the subsurface in order re-pressurize the reservoir so as to increase oil and gas production in exhausted fields, where primary production is no longer possible.

8. For many years, naturally occurring $\mathrm{CO}_{2}$ has been produced from wells in the San Juan Basin of New Mexico and Colorado and transported by pipeline to southwest Texas where it is used for enhanced petroleum recovery. And $\mathrm{CO}_{2}$ produced as a by-product of a coal gasification plant in North Dakota is captured and transported by pipeline to Saskatchewan where it is used for enhanced petroleum recovery. This latter project also includes an experimental GCS project, which is studying the utility of using depleted petroleum reservoirs for long-term carbon storage. 
gas producing states, ${ }^{9}$ are already attempting to create GCS-specific legislation that best avoids conflict with other economic uses of the subsurface. ${ }^{10}$

Subsurface formations with hydrocarbon-bearing strata are typically wellcharacterized and are often stacked between non-hydrocarbon-bearing saline aquifers. ${ }^{11}$ Currently, oil wells and natural gas wells operate at average depth of 1,700 meters $(5,600$ feet). These depths are similar to the depths of proposed $\mathrm{CO}_{2}$ sequestration projects. ${ }^{12}$ The possibility of developing a $\mathrm{CO}_{2}$ sequestration site above or below oil or natural gas reservoirs or within depleted reservoirs may have the advantage of reducing characterization and capital costs compared to an uncharacterized site, but doing so could also create potential interference between projects. ${ }^{13}$ The potential subsurface impacts of $\mathrm{CO}_{2}$ injection are varied. In a reservoir with active hydrocarbon resource production, particularly natural gas, migrating $\mathrm{CO}_{2}$ could commingle directly with the resource and require efforts to remove the $\mathrm{CO}_{2}$ from the production stream. ${ }^{14}$ Soluble $\mathrm{CO}_{2}$ could cause the precipitation of carbonate minerals and plug flow paths, which would reduce the extraction efficiency for existing hydrocarbon production facilities. ${ }^{15}$ The pressure effects from the injection operation, particularly if multiple sites are used to inject $\mathrm{CO}_{2}$ into a single basin, could adversely affect other injection operations by potentially altering injectibility, plume size and shape, and associated monitoring. ${ }^{16}$

9. See, e.g., Wyo. STAT. ANN. §§ 34-1-152; 34-1-313-17 (2009). See generally INTERSTATE OIL AND GAS COMPACT COMM'N TASK ForCE ON CARbON CAPTURE AND GEOLOGIC STORAGE, STORAGE OF Carbon Dioxide in Geologic Structures, a legal and Regulatory Guide for States and Provinces, Appendix I: Model Statute For GeOlogic Storage of CARbon Dioxide 31-35 (2007). The Task Force has also drafted model regulations. $I d$. at ApPendiX II: Model General Rules AND REGULATIONS 36-47.

10. See generally April Reese, Climate: States Moving to Clarify Landowners' Rights over $\mathrm{CO}_{2}$ Storage Space, Land Letter, Feb. 26, 2009, http://www.eenews.net (noting that some states are also attempting to write clauses in GCS legislation that protect existing resources and property interests).

11. See, e.g., Christine Doughty \& Karsten Pruess, Modeling Supercritical Carbon Dioxide Injection in Heterogeneous Porous Media, 3 VAdose ZoNe J. 837 (2004).

12. U.S. Energy Info. Admin., Average Depths of Crude Oil and Natural Gas Wells, http://tonto.eia .doe.gov/dnav/pet/pet_crd_welldep_s1_a.htm (last visited July 21, 2010).

13. Sally Benson et al., Underground Geologic Storage, in IPCC SPECIAL REPORT ON CARBON Dioxide CAPTURE AND STORAGE 195, 210 (Bert Mertz et al. eds., 2005) (stating that the presence of CO2 in the basin can lead to corrosion problems and can change the composition such that plugging, erosion, and processing problems arise).

14. See id.

15. Sally M. Benson \& David R. Cole, $\mathrm{CO}_{2}$ Sequestration in Deep Sedimentary Formations, 4 ELEMENTS 325, 328 (2008); see also William Gunter et al., The Role of Hydrogeological and Geothermal Trapping in Sedimentary Basins for Secure Storage of Carbon Dioxide, in Geological Storage of CARBON DIOXIDE 129, 135 (S.J. Baines \& R.H. Worden eds., 2004).

16. SARAh Forbes ET AL., World Resources InStitute, CCS Guidelines 62-63 (2008). 
Hydrocarbon production also produces large amounts of wastewater-an average of seven gallons of water is produced for each gallon of oil. The produced water must be separated and disposed of safely, usually by underground injection. ${ }^{17}$ Over 750 billion gallons of oil-produced waters ${ }^{18}$ are injected into the subsurface though 150,000 disposal wells in the United States each year. ${ }^{19}$ This volume of produced water is the rough equivalent of the volume that 2 gigatonnes (Gt) of $\mathrm{CO}_{2}$ would occupy at a depth of one kilometer. ${ }^{20}$ The wastewater is generally handled on site, with approximately one-quarter of it being injected back into the oil producing formation, in part to increase oil production..$^{21}$ Other operators inject the produced waters into non-producing formations at varying depths where formations of adequate porosity and permeability are present. ${ }^{22}$ Some wastewater disposal wells inject below the hydrocarbon formation and others inject above it. ${ }^{23}$ In Texas, produced water is injected into non-producing formations varying in depth from 300 to 3,000 meters (1,000 to 9,800 feet), with $60 \%$ of these wells a kilometer or more deep. ${ }^{24}$ Both the practice and scale of handling produced water is similar to those expected for geologic sequestration of $\mathrm{CO}_{2} \cdot{ }^{25}$

Underground natural gas storage is another area where use of the subsurface for $\mathrm{CO}_{2}$ sequestration may require coordination. Gas storage has helped to balance the supply and demand fluctuations of natural gas around the world for nearly 100 years. In many ways, underground gas storage is a useful analog for $\mathrm{CO}_{2}$ sequestration. ${ }^{26}$ Similar to sequestration, depleted hydrocarbon fields and saline aquifers are commonly used for natural gas storage ${ }^{27}$ Injected $\mathrm{CO}_{2}$ will readily mix with natural gas. If natural gas storage and $\mathrm{CO}_{2}$ sequestration are operated in close proximity within the same geologic

17. John Veil et al., Argonne Nat'l Laboratory, A White Paper Describing Produced WAter from Production of Crude Oil, Natural Gas, and CoAl Bed Methane 17 (2004).

18. Produced water is the industry term for brine that is extracted as a part of oil or gas production.

19. Benson et al., supra note 13, at 212; see also M.G. PUDER \& J.A. VeIL, ARGONNE NAT'L LAB.,

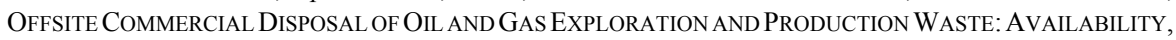
OPTIONS, AND COSTS 39 (2006).

20. Benson et al., supra note 13, at 212 .

21. VEIL ET AL., supra note 17, at 49.

22. Id. at $49-50$.

23. Id. at 34 .

24. Klass \& Wilson, supra note 3, at 384-93 (citing Melisa Pollak, Produced Water Disposal: Comparison to Geological Sequestration of CO2, at $1 \mathrm{n} .3$ (Jan. 29, 2009) (unpublished manuscript) (on file with author Gresham).

25. Benson et al., supra note 13, at 234.

26. Id. at 211 .

27. $I d$. 
formation, the two substances might commingle and degrade the quality of the natural gas. ${ }^{28}$ Today in the United States, there are roughly 130 natural gas operators storing between 1,200 and 3,300 billion cubic feet (BCF) of natural gas throughout more than 400 active storage facilities in the lower 48 states. $^{29}$

In addition, long-standing and new uses of the subsurface for activities wholly unrelated to hydrocarbon production may take place in formations and depths similar to $\mathrm{CO}_{2}$ sequestration. For example, hazardous and nonhazardous fluid wastes and municipal wastewater are often disposed of below the lowest underground source of drinking water by injecting them deep into subsurface formations. ${ }^{30}$ The Environmental Protection Agency (EPA) and delegated state agencies have regulated the underground injection of fluid wastes under the Underground Injection Control (UIC) program by creating "classes" of injection wells and setting standards for injection to protect underground sources of drinking water. These waste injection wells are located in formations where fresh water is protected from the injection zone by an impermeable caprock or confining layer, much like what would be used for $\mathrm{CO}_{2}$ sequestration. Injection zones typically range from slightly over 500 $(1,600)$ meters to more than 3,000 meters $(9,800$ feet $)$ in depth. ${ }^{31}$ There are roughly 550 Class I wells in the United States, mostly located in the sedimentary basins of the Gulf Coast and Great Lakes regions. ${ }^{32}$ While approximately $48 \%$ of the Class I wells are for non-hazardous wastes, another $30 \%$ of the wells are dedicated to municipal wastewater disposal in Florida, where over 3 billion metric tons of wastewater are injected annually. ${ }^{33}$

Finally, compressed air energy storage (CAES) and underground aquifer storage and recovery (ASR) of ground water both have become increasingly attractive uses of the subsurface. CAES could help manage complications imposed by the intermittency of large-scale electricity produced by wind. Surplus electricity produced by wind that would otherwise flow into the

28. Stefan Bachu, Sequestration of $\mathrm{CO}_{2}$ in Geologic Media: Criteria and Approach for Site Selection in Response to Climate Change, 41 ENERGy CONVERSION \& MGMT. 953, 964 (2000).

29. U.S. Energy Info. Admin., Weekly Natural Gas Storage Report, http://www.eia .doe.gov/oil_gas/natural_gas/ngs/ngs.html (last visited Feb. 20, 2011); WILLIAM TRAPMAN, U.S. ENERGY INFo. Admin., U.S. WeEkly Natural Gas Storage Data, http:/www.eia.doe.gov/pub/oil_gas/ natural_gas/presentations/2007/ngsdata/ngsdata_files/frame.html (2007) (last visited Mar. 15, 2011).

30. VEIL ET AL., supra note 17, at 34.

31. See EPA, EPA 816-R-01-007, Class I Underground InJeCtion CONTROL Program: Study OF RISKS ASSOCIATED WITH CLASS I UNDERGROUND INJECTION WELLS 12 (2001).

32. EPA, Industrial \& Municipal Waste Disposal Wells (Class I), http://www.epa.gov/safewater/uic/ wells_class1.html (last visited July 21, 2010).

33. Id.; see also David W. Keith et al., Regulating the Underground Injection of $\mathrm{CO}_{2}, 39$ ENVTL. SCI. \& TECH. 499A, 501A (2005). 
electric grid could instead be used to compress air that is pumped and stored in deep geologic reservoirs to be used later to make natural gas turbines operate more efficiently. ${ }^{34}$ A 290 megawatt (MW) CAES plant operating in Germany has been compressing roughly 300,000 cubic meters of air in a natural gas storage reservoir roughly 600 to 800 meters (2,000 to 2,600 feet) below the surface. ${ }^{35}$ A 110 MW CAES plant is also currently operating in the United States in McIntosh, Alabama. ${ }^{36}$ The Battelle Memorial Institute suggested that future United States compressed air storage projects should be located in formations roughly 650 to 850 meters (2,100 to 2,800 feet) below the surface and at least 100 meters (330 feet) away from any dissimilar geologic formation. ${ }^{37}$

ASR involves injecting water into deep underground reservoirs for later retrieval. ${ }^{38} \mathrm{~A}$ handful of states have mature permitting regimes to facilitate the storage of fresh water underground so that it may be withdrawn during dry periods. ASR is thought to be a promising solution for the future of freshwater management. ${ }^{39}$

Thus, there exists the very real potential for GCS operations to interfere with actual or foreseeable uses of subsurface pore space. Currently, there is little to no federal or state statutory authority governing subsurface property rights issues in the context of $\mathrm{CO}_{2}$ sequestration. Moreover, many subsurface injection activities discussed in the preceding paragraphs are permitted and regulated by different federal and state agencies. The federal Safe Drinking Water Act (SDWA) gives the EPA authority to manage the UIC program, which regulates underground fluid waste injection activities and enhanced oil recovery, but not natural gas storage. ${ }^{40}$ Many states have asserted primacy to

34. See Paul Denholm \& Ramteen Sioshansi, The Value of Compressed Air Energy Storage with Wind in Transmission-Constrained Electric Power Systems, 37 ENERGY POL'y 3149, 3149-50 (2009).

35. See Fritz Crotogino et al., Huntorf CAES: More than 20 Years of Successful Operation, http://www.uni-saarland.de/fak7/fze/AKE_Archiv/AKE2003H/AKE2003H_Vortraege/ AKE2003H03c_Crotogino_ea_HuntorfCAES_CompressedAirEnergyStorage.pdf(last visited July 7, 2010).

36. Id.

37. R.D. Allen et Al., Battelle Memorial Institute, Geotechnical Issues and Guidelines FOR StORAGe of COMPRESSED AIR IN EXCAVATED HARd Rock CAVERnS, at xiii (1982), http://www .google.com/url?sa=t\&source=web\&cd=2\&ved=0CBYQFjAB\&url=http $\% 3 \mathrm{~A} \% 2 \mathrm{~F} \% 2 \mathrm{Fwww}$. osti.gov $\% 2$

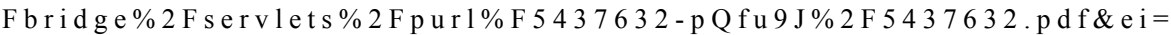
ihNHTMCnL8P48Ab8rfHzBA\&usg=AFQjCNHrgh8_n4Rjt_81XxZZsXEi5tEheQ (last visited July 7, 2010).

38. State of Washington Dep't of Ecology, Aquifer Storage and Recovery, http://www.ecy.wa.gov/ programs/wr/asr/asr-home.html (last visited July 7, 2010).

39. Peter J. Kiel \& Gregory A. Thomas, Banking Groundwater in California: Who Owns the Aquifer Storage Space?, 18 NAT. RESOURCES \& ENV'T, Fall 2003, at 25, 25.

40. 40 C.F.R $\S \S 144-146$ (2010). 
administer the UIC program, but may do so through more than a single state agency. For example, in many petroleum producing states, oil and gas conservation agencies manage the UIC program regarding saltwater disposal and injections related to petroleum operations, while another agency manages other UIC matters.

The EPA determined that the SDWA confers to the Agency the authority to regulate geologic sequestration of $\mathrm{CO}_{2}{ }^{41}$ In November of 2010, the EPA published its final rules for managing the injection of $\mathrm{CO}_{2}$ for geologic sequestration under the UIC program. ${ }^{42}$ The rules include provisions for onsite characterization, well construction and operation, post-injection monitoring, and post-closure stewardship. ${ }^{43} \mathrm{GCS}$-specific property rights and pore-space use issues, however, are not addressed in the new rule. ${ }^{44}$

\subsection{Who Owns Pore Space in the United States?}

In the United States, property rights historically have been defined by state law rather than federal law. Common law property rights are generally viewed as a bundle of rights that together define how ownership of various resources are divided, and establish limitations on the use of each by the owner. A typical bundle of rights might be: (1) surface rights; (2) rights to coal; (3) rights to natural gas; (4) rights to oil; (6) rights to minerals other than coal, oil, and natural gas (sometimes referred to as residual mineral ownership); (7) rights to ground water; and (8) rights to storage (e.g., natural gas and fresh water). These various interests may be burdened by licenses, leases, servitudes, and security interests.

Today's reality is that there exists no uniformity in the way that the right to inject fluids of any kind into deep subsurface pore space is legally recognized, acquired, or authorized. In the United States, under the commonlaw maxim cujus est solum, ejus est usque ad coelum et ad inferos (commonly known as the "ad coelum doctrine"), ${ }^{45}$ a fee simple ${ }^{46}$ owner of land holds title

41. See Safe Drinking Water Act, 42 U.S.C. § 300(h)(d) (2006); see also U.S. Envtl. Prot. Agency, Geological Sequestration of Carbon Dioxide, http://www.epa.gov/safewater/uic/wells_sequestration.html (last visited July 21, 2020).

42. Envtl. Prot. Agency, Federal Requirements Under the Underground Injection Control (UIC) Program for Carbon Dioxide Geologic Sequestration Wells, 75 Fed. Reg. 77230-303 (Dec. 10, 2010).

43. $I d$.

44. Id.

45. 1 CoKe, Institutes, ch. $1, \S 1$ (4a) (19th ed. 1832); 2 BlaCKSTONE, COMMENTARIES *18(Lewis ed., 1902); 3 Kent, COMMENTARIES *621 (Gould ed., 1896).

46. Means the mineral and surface interests are held by a single owner. See BLACK's LAW 
to the entire tract from the heavens to the depths of the earth. Under this maxim, a fee simple owner would own the subsurface pore space. The question of pore-space ownership most commonly arises when the fee-simple interest is severed into a surface estate and one or more separate mineral interests. As between the surface owner and mineral owner, few states have statutorily or judicially determined who owns the pore space. In many states, the questions of pore-space ownership and use rights would be ones of first impression. To date, only a handful of cases across the country have addressed this issue, with the vast majority and better-reasoned decisions holding (given the specific facts before the court) that the surface owner owns the pore space. ${ }^{47}$ However, even though a surface owner may "own" pore spaces, the mineral owner has an implicit right of reasonable use to facilitate enjoyment

DICTIONARY 648 (8th ed. 2004).

47. See, e.g., Sunray Oil v. Cortez Oil Co., 112 P.2d 792 (Okla. 1941) (surface owner has the right to grant permission to inject wastewater into the subsurface as long as there is not interference with the mineral estate's recovery of oil and gas); Cent. Ky. Natural Gas Co. v. Smallwood, 252 S.W.2d 866 (Ky. Ct. App. 1952) (the mineral owner has the authority to grant a gas-storage lease); Tate v. United Fuel Gas Co., 71 S.E.2d 65 (W. Va. 1952) (based on exception language in the deed, the oil and gas owner did not own "clay, sand, or stone," and thus did not own the spaces in the storage formation, which were devoid of recoverable gas); Emeny v. United States, 412 F.2d 1319, 1324 (Ct. Cl. 1969) (ownership of "all gas in or under, or which may hereafter be found in or under and produced from the lands" did not include the right to store helium produced from other lands; such right remained with the non-mineral owner.); Miles v. Home Gas Co., 316 N.Y. Supp. 2d 908 (N.Y. Sup. Ct. App. Div. 1970) (surface owner); Humble Oil \& Ref. Co v. West, 508 S.W.2d 812 (Tex. 1974) (surface owner, citing Emeny v. United States); Ellis v. Ark. La. Gas Co., 450 F. Supp. 412 (E.D. Okla. 1978) (storage company must obtain permission from the surface owner to store natural gas); United States v. 43.42 Acres of Land, 520 F. Supp. 1042, 1043, 1046 (W.D. La. 1981) (stated "the mineral owner cannot be considered to have ownership of the subsurface strata containing the spaces where the minerals are found.”); Rook v. James E. Russell Petroleum, Inc., 679 P.2d 158, 166-67 (Kan. 1984) (although Kansas has not directly addressed pore-space ownership, such rights are considered severable from the right to produce oil and gas); Miss. River Transmission Corp. v. Tabor, 757 F.2d 662, 672 (5th Cir. 1985) (surface owner owns storage rights); Grynberg v. City of Northglenn, 739 P.2d 230 (Colo. 1987) (court's dubious holding that surface owner did not have a right to test for coal to determine suitability of land for a surface water reservoir suggests the possibility that mineral owner controls access to pore spaces); Int'l Salt Co. v. Geostow, 697 F. Supp. 1258 (W.D.N.Y. 1988) (salt miner given continued access to mined salt cavern to facilitate ongoing salt mining operation possibly suggesting that mineral owner controls access to pore spaces); Mapco, Inc. v. Carter, 808 S.W.2d 262 (Tex. App. 1991) (mineral owner, but inconsistent with West, above); Chance v. BP Chemicals, Inc., 670 N.E.2d 985 (Ohio 1996) (the court found that "ownership rights in today's world are not as clear-cut as they were before the advent of airplanes and injections wells"); Dep't of Transp. v. Goike, 560 N.W.2d 365, 365 (W.D. Mich. 2006) (court held that the storage space, once it has been evacuated of the minerals and gas, belongs to the surface owner). See generally Alan Stamm, Legal Problems in the Underground Storage of Natural Gas, 36 TEX. L. REV. 161, 164-69 (1957); Roger R. Scott, Underground Storage of Natural Gas: A Study of Legal Problems, 19 OKLA. L. REV. 47, 56-63 (1966); Fred McGaha, Underground Gas Storage: Opposing Rights and Interests, 46 LA. L. REV. 871 (1986); Wilson \& de Figueiredo, supra note 3, at 10121-22; Anderson I, supra note 3, at 99-109; Klass \& Wilson, supra note 3, at 384-93. Lillibridge v. Lackawanna Coal Co., 22 A. 1035 (Pa. 1891) (holding that coal owners, not surface owners, owned coal-mining shafts). 
of mineral rights. Because mineral rights may be severed by specific substances or by depth, are frequently fractionalized among multiple parties, and are subject to a multitude of transactions and property interests, a single tract of land could be subject to a variety of mineral claims held by literally dozens - perhaps hundreds and even thousands — of claimants.

The emerging opinion, ${ }^{48}$ that pore-space rights generally belong to the surface owner, is not founded on the idea that surface rights and pore-space rights are inextricably bound together. Instead, the opinion is based on the recognition that, as a historical matter: (1) owners of fee-simple estates traditionally have owned everything on, above, or below the surface except to the extent particular rights have been granted to others; (2) historically, feesimple owners have tended to retain ownership of the surface when carving mineral interests out of the fee for transfer to others; (3) legal instruments transferring a portion of the fee-simple owner's property rights to others have tended to be narrowly drafted; and 4) courts generally interpret such instruments to have transferred only what is specifically mentioned together with whatever other rights are necessarily associated with the rights explicitly identified. ${ }^{49}$

For example, legal documents creating severed mineral interests have typically used narrow language such as granting or reserving "oil, gas and other minerals" rather than broad language that would sever everything below the surface of the land from the surface interest. In the former case, the owner of particular mineral interest generally will have the right to use the pore space

48. Recent white papers and law review articles have analyzed whether, in the first instance, the surface owner or the mineral owner on split-estate land has property rights in the pore space. While most of these papers and articles conclude that the surface owner would prevail over the mineral owner in most cases, the issue is far from resolved. See DAVID COONEY, ANALYSIS OF PROPERTY RIGHTS ISSUES RELATED to Underground Storage Space Used for Geologic Sequestration of CARbon Dioxide, IOGCC Task Force on Carbon Capture and Geologic Storage, Subgroup of State Oil and Gas ATtORNEYs (2005); Mark A. de Figueiredo, The Liability of Carbon Dioxide Storage (2007) (unpublished Ph.D. Thesis, MIT Engineering Systems Division), available at http://web.mit.edu/defig/www/ publications.html (last visited Nov. 16, 2011); Wilson \& de Figueiredo, supra note 3, at 10121-22 (stating that most courts have held that after the removal of underground minerals, oil, or gas, the surface owner retains the right to use the remaining space for storage but that mineral rights holders often retain some rights to access the pore space for continued exploration or extraction of minerals in other areas); Anderson I, supra note 3, at 99-109 (stating that Texas and other jurisdictions have not specifically determined who owns subterranean pore space as between a mineral owner and a surface owner but, based on existing case law and legal doctrine, the most "likely" owner of the pore space is the surface owner); Klass \& Wilson, supra note 3, at 366 (stating "there are protectable property interests in pore space that are vested in the surface owner, the mineral owner, or both").

49. See Anderson I, supra note 3, at 99-109; Ian Duncan, Scott Anderson \& Jean-Philippe Nicot, Pore Space Ownership Issues for CO2 Sequestration in the U.S., 1 ENERGY PROCEDIA 4427, 4430 (2009). 
as reasonably necessary to extract minerals, but the mineral owner is not likely to "own" the pore space or to have the right to use the pore space for purposes unrelated to extracting minerals. The latter case is very rare. Thus, American jurisdictions, grounded in English Common Law, will most likely find that pore space is owned by surface owners.

Several states have begun to develop regulatory frameworks to manage geologic sequestration of $\mathrm{CO}_{2}$, with specific attention directed towards the issue of pore-space ownership. As shown in Table 1, Wyoming, Montana, and North Dakota passed legislation explicitly defining pore-space ownership. ${ }^{50}$ Wyoming H.B. 89 addressed the issue of property rights by stating that " $[t]$ he ownership of all pore space in all strata below the surface lands and waters of this state is declared to be vested in the several owners of the surface above the strata." ${ }^{51}$ In 2009, the Wyoming governor signed into law H.B. 57, which amends the pore-space provision in H.B. 89 and clarifies that the mineral estate is still dominant over the surface estate. ${ }^{52}$ That same year, North Dakota S.B. 2139 similarly proclaimed that "[t]itle to pore space in all strata underlying the surface lands and waters vested in the owner of the overlying surface estate. ${ }^{~} 53$ North Dakota's bill further attaches pore-space rights to the surface estate by prohibiting severance of pore space from the title to the overlying surface property. ${ }^{54}$ Montana S.B. 498 creates a presumption that the surface owner owns subsurface pore space if deeds or other severance documents do not demonstrate otherwise. ${ }^{55}$ Like Wyoming and North Dakota, Montana's new statute explicitly does not interfere with common law or the dominance of the mineral estate. West Virginia's new legislation creates a working group that will make recommendations to the legislature on porespace ownership by $2011 .^{56}$

50. See Mont. Code AnN. § 82-11-180 (2009); N.D. Cent. Code § 47-31-02 (2006 \& Supp. 2009); WYO. STAT. ANN. § 34-1-152 (2009).

51. Wyo. STAT. ANN. § 34-1-152(a) (2009).

52. Wyo. STAT. ANN. § 34-1-152(a) (2009).

53. N.D. CENT. CODE § 47-31-04 (2006 \& Supp. 2009).

54. Id. (codified at N.D. CENT. CODE $\S 47-31-05$ (2009))

55. Mont. COdE ANN. § 82-11-180 (2009).

56. W. VA. CODE $\S 22-11$ A-6 (2009). 
Table 1: Existing state GCS legislation regarding subsurface property rights. $^{57}$

\begin{tabular}{|c|c|c|c|c|c|}
\hline & \begin{tabular}{|l|} 
REGULATORY \\
AUTHORITY \\
\end{tabular} & $\begin{array}{l}\text { PORE-SPACE } \\
\text { OWNERSHIP }\end{array}$ & EMINENT DOMAIN & UNITIZATION & $\begin{array}{l}\text { MINERAL RIGHTS } \\
\text { DOMINANCE }\end{array}$ \\
\hline $\begin{array}{l}\text { LOUISIANA } \\
\text { H.B. } 1117(2008) \text {; } \\
\text { H.B. } 1220(2008) \text {; } \\
\text { H.B. } 661 \text { (2009) }\end{array}$ & $\begin{array}{l}\text { Office of } \\
\text { Conservation, } \\
\text { Department of } \\
\text { Natural } \\
\text { Resources }\end{array}$ & NA & $\begin{array}{l}\mathrm{CO}_{2} \text { sequestration } \\
\text { declared to be in the } \\
\text { public interest; } \\
\text { public and private } \\
\text { entities may } \\
\text { exercise eminent } \\
\text { domain subject to } \\
\text { certain conditions }\end{array}$ & NA & NA \\
\hline $\begin{array}{l}\text { MontANA } \\
\text { S.B. } 498 \text { (2008) }\end{array}$ & $\begin{array}{l}\text { Board of Oil } \\
\text { and Gas } \\
\text { Conservation, } \\
\text { with comments } \\
\text { from the Board } \\
\text { of Environ- } \\
\text { mental Review }\end{array}$ & $\begin{array}{l}\text { Surface owner } \\
\text { (severance } \\
\text { allowed) }\end{array}$ & NA & $\begin{array}{l}\text { Owners of } 60 \% \\
\text { or more of the } \\
\text { pore space may } \\
\text { apply to the } \\
\text { Board of Oil } \\
\text { and Gas } \\
\text { Conservation to } \\
\text { have the area } \\
\text { treated as a unit }\end{array}$ & $\begin{array}{l}\text { Common law and } \\
\text { mineral estate } \\
\text { dominance not altered } \\
\text { by GCS legislation }\end{array}$ \\
\hline $\begin{array}{l}\text { NORTH DAKOTA } \\
\text { S.B. } 2095(2009) ; \\
\text { S.B. } 2139(2009) ; \\
\text { N.D. Admin. } \\
\text { Code 42-02-04.1 } \\
\text { (proposed) }\end{array}$ & $\begin{array}{l}\text { Industrial } \\
\text { Commission }\end{array}$ & $\begin{array}{l}\text { Surface owner } \\
\text { (severance not } \\
\text { allowed) }\end{array}$ & $\begin{array}{l}\mathrm{CO}_{2} \text { sequestration } \\
\text { declared to be in the } \\
\text { public interest }\end{array}$ & $\begin{array}{l}\text { Owners of } 60 \% \\
\text { or more of the } \\
\text { pore-space } \\
\text { owners must } \\
\text { consent }\end{array}$ & $\begin{array}{l}\text { Common law and } \\
\text { mineral estate } \\
\text { dominance not altered } \\
\text { by GCS legislation }\end{array}$ \\
\hline $\begin{array}{l}\text { ОКLАНОМА } \\
\text { S.B. } 610(2009) ; \\
\text { S.B. } 1765(2008)\end{array}$ & $\begin{array}{l}\text { Corporation } \\
\text { Commission } \\
\text { (for fossil fuel- } \\
\text { bearing } \\
\text { formation); } \\
\text { Department of } \\
\text { Environmental } \\
\text { Quality for all } \\
\text { other } \\
\text { formations }\end{array}$ & NA & $\begin{array}{l}\mathrm{CO}_{2} \text { sequestration } \\
\text { declared to be in the } \\
\text { public interest }\end{array}$ & $\begin{array}{l}\text { Corporation } \\
\text { Commission } \\
\text { will be the } \\
\text { regulatory } \\
\text { authority if a } \\
\text { unitization } \\
\text { process is } \\
\text { adopted }\end{array}$ & $\begin{array}{l}\text { Common law and } \\
\text { mineral estate } \\
\text { dominance not altered } \\
\text { by GCS legislation }\end{array}$ \\
\hline $\begin{array}{l}\text { WEST VIRGINIA } \\
\text { H.B. } 2860(2009)\end{array}$ & $\begin{array}{l}\text { Department of } \\
\text { Environmental } \\
\text { Protection }\end{array}$ & $\begin{array}{l}\mathrm{CO}_{2} \\
\text { Sequestration } \\
\text { Working } \\
\text { Group to make } \\
\text { recommenda- } \\
\text { tions in } 2011\end{array}$ & NA & NA & $\begin{array}{l}\text { Common law and } \\
\text { mineral estate } \\
\text { dominance not altered } \\
\text { by GCS legislation }\end{array}$ \\
\hline
\end{tabular}

57. Adapted from Klass \& Wilson, supra note 3, at 383-84; Melisa Pollak \& Elizabeth J. Wilson, Regulating Geologic Sequestration in the United States: Early Rules Take Divergent Approaches, 43 ENVTL. SCI. \& TECH. 3035, 3036-38 (2009). 


\begin{tabular}{|c|c|c|c|c|c|}
\hline & \begin{tabular}{|l} 
REGULATORY \\
AUTHORITY \\
\end{tabular} & $\begin{array}{l}\text { PORE-SPACE } \\
\text { OWNERSHIP }\end{array}$ & EMINENT DOMAIN & UNITIZATION & $\begin{array}{c}\text { MINERAL RIGHTS } \\
\text { DOMINANCE }\end{array}$ \\
\hline $\begin{array}{l}\text { WyоміNG } \\
\text { H.B. } 89 \text { (2008); } \\
\text { H.B. } 57 \text { (2009); } \\
\text { H.B. } 58(2009) ; \\
\text { H.B. } 80 \text { (2009); } \\
\text { Water Qual. Rules } \\
\text { \& Regs. Chap. } 24 \\
\text { (proposed) }\end{array}$ & $\begin{array}{l}\text { Department of } \\
\text { Environmental } \\
\text { Quality }\end{array}$ & $\begin{array}{l}\text { Surface owner } \\
\text { (severance } \\
\text { allowed) }\end{array}$ & NA & $\begin{array}{l}\text { Any interested } \\
\text { person may } \\
\text { apply to treat } \\
\text { project area } \\
\text { as a unit; Oil } \\
\text { and Gas } \\
\text { Conservation } \\
\text { Commission } \\
\text { may approve if } \\
\text { owners of at } \\
\text { least } 80 \% \text { of } \\
\text { pore-space } \\
\text { owners consent }\end{array}$ & $\begin{array}{l}\text { Affirms dominance of } \\
\text { the mineral estate }\end{array}$ \\
\hline
\end{tabular}

1.2. Does the Use of Pore Space for GCS Require Compensation Under the Law?

The Takings Clause of the Fifth Amendment to the U.S. Constitution instructs that private property shall not "be taken for public use, without just compensation." 58 The Supreme Court of the United States explained that the Takings Clause "was designed to bar Government from forcing some people alone to bear public burdens which, in all fairness and justice, should be borne by the public as a whole." 59 The Constitution does not create or define the scope of property interests that are protectable under the Fifth Amendment, but instead requires compensation in the event that an impairment of those property interests amounts to a taking. ${ }^{60}$ To determine whether a protectable property interest exists, courts look to "existing rules or understandings" and "background principles" derived from sources such as Federal and state common law. ${ }^{61}$ Even though property rights typically fall under the purview of state law, state-created property rights may be limited by federal law. ${ }^{62}$

58. U.S. CONST. amend. V.

59. Armstrong v. United States, 364 U.S. 40, 49 (1960).

60. Phillips v. Wash. Legal Found., 524 U.S. 156, 164 (1998) (“[T]he Constitution protects rather than creates property interests ...").

61. Lucas, 505 U.S. at $1032 \mathrm{n} .18$ (stating that state law definitions of private property rights must be based on "an objectively reasonable application of relevant precedents" (emphasis omitted)); Klamath Irrigation, $67 \mathrm{Fed}$. Cl. at $515 \mathrm{n} .15$ (stating an objective basis in defining property rights is "vital if the integrity of the Takings Clause is to be preserved as against entirely novel and unprincipled definitions of property designed artificially to defeat or buttress a takings claim") (citing Webb's Fabulous Pharmacies, Inc v. Beckwith, 449 U.S. 155, 164 (1980)).

62. Bair v. United States, 515 F.3d 1323, 1327-28 (Fed. Cir. 2008) (recognizing that "state-created property interests may be limited by federal law" and that federal law can constitute "background principles" that can prevent a per se takings claim). 
In the context of $\mathrm{CO}_{2}$ sequestration, the threshold question is therefore whether a surface owner or mineral owner has sufficient interests in subsurface pore space to implicate the Takings Clause of the Fifth Amendment to the Constitution, or similar limitations imposed by state constitutions. There is little dispute that, subject to reasonable regulation, property owners have significant rights to use their property as they see fit. Just as importantly, property owners have the right to exclude others from making use of their property without consent. If the federal or state governments wish to confiscate private property, condemn private property, or authorize third parties to confiscate or condemn private property for a public purpose, then they may do so through the exercise of eminent domain. Eminent domain authority is conditional, however, and requires that "just compensation" be paid to the property owner.

If a government action is challenged as having impaired an established property interest, then a court must decide whether to analyze the action as a physical taking or as a regulatory taking. ${ }^{63}$ A physical taking occurs when the government engages in, or authorizes a third party to engage in, a permanent physical occupation of private property.$^{64}$ In the case of physical invasions, "no matter how minute the intrusion, and no matter how weighty the public purpose behind it," a taking has occurred and just compensation is required. ${ }^{65}$ Even when there is no physical occupation of private property, a regulatory taking can occur if government regulation places too great a burden on the owner's use of the property. ${ }^{66}$ A regulatory taking can take place under two circumstances ${ }^{67}$ First, a regulatory action can be what is known as a per se taking when the regulation completely deprives a property owner of all economically beneficial use of the property. ${ }^{68}$ Second, in the absence of a complete deprivation of all economic use of property, courts will consider whether the regulatory restriction rises to the level of a compensable taking under the multifactor balancing test prescribed in Penn Central Transportation

63. Lingle v. Chevron U.S.A. Inc., 544 U.S. 528, 538 (2005).

64. Chevron, 544 U.S. at 538; Loretto v. Teleprompter Manhattan CATV Corp., 458 U.S. 419, 426 (1982) (holding that state regulation requiring landlords to allow television cable companies to place cable facilities in their apartment buildings constituted a taking even though the facilities occupied at most only one and one-half cubic feet of the landlord's property).

65. Loretto, 458 U.S. at 426; Lucas, 505 U.S. at 1015. See also Brown v. Legal Found. of Wash., 538 U.S. 216, 233-34 (2003).

66. See Tahoe-Sierra Pres. Council, Inc. v. Tahoe Reg'1 Planning Agency, 535 U.S. 302, 326 (2002).

67. Chevron, 544 U.S. at 538.

68. Lucas, 505 U.S. at 1029 (holding that regulations which prohibit all economically beneficial use of land are just as much a taking requiring compensation as permanent physical occupations of land). 
Co. v. New York City. ${ }^{69}$ The Penn Central balancing test, as it is commonly known, considers: (1) the character of the government action; (2) the severity of the economic impact; and (3) the extent to which the regulation interferes with the property owner's distinct, "investment-backed" expectations. ${ }^{70}$ However, even if a government action constitutes a physical taking or regulatory taking, a violation of the Fifth Amendment occurs only if the taking is without "just compensation." "71 Consequently, if a court concludes that the monetary value of property owner's net loss as a result of the taking is zero, the compensation due under the Constitution is also zero. ${ }^{72}$

The questions of how far up into the sky and down into the earth property rights extend and to what extent these rights are protected are also encountered. As noted above, the ad coelum doctrine instructs that the rights of the surface owner extend up to the heavens (ad coelum) and down to the center of the earth (ad infernos). However, ever since the advent of air travel in the early part of the 20th century, the doctrine no longer applies in absolute terms to ownership of airspace high above the ground. Courts continued to advance the expansive view of airspace rights invoked in the ad coelum doctrine until the invention of the airplane sparked litigation in the $1930 \mathrm{~s}^{73}$ Subsequently, the use of airspace by airplanes is generally not compensable unless a landowner suffers actual damages. ${ }^{74}$ In Hinman v. Pacific Air Lines Transport Corp. ${ }^{75}$ the United States Court of Appeals for the Ninth Circuit observed that the ad coelum doctrine was "invented at some remote time in the past when the use of space above land actual or conceivable was confined to narrow limits, and simply meant that the owner of the land could use the overlying space to such an extent as he was able, and that no one could ever interfere with that use." $" 76$ The court further observed that the doctrine was "never taken literally, but was a figurative phrase used to express the full and complete ownership of land and the right to whatever super-adjacent airspace was necessary or convenient to the enjoyment of the land ... Title to the

\footnotetext{
69. Penn Cent. Transp. Co. v. New York City, 438 U.S. 104 (1978).

70. Id. at 124 .

71. See Brown v. Legal Found. of Wash., 538 U.S. 216, 235 (2003).

72. Id. at 237.

73. See John G. Sprankling, Owning the Center of the Earth, 55 UCLA L. REV. 979, 1000 (2008).

74. See, e.g., Hinman v. Pac. Air Lines Transp. Corp., 84 F.2d 755, 758-59 (9th Cir. 1936) (holding that the use of airspace is not unlawful without proof of actual injury); United States v. Causby, 328 U.S. 256 (1946) (recognizing that airplanes may freely navigate airspace unless the flights are so low and constant as to make it impossible for the true owner to fully enjoy and use the surface estate).

75. Hinman v. Pac. Air Lines Transp. Corp., 84 F.2d 755 (9th Cir. 1936).

76. Id. at 757 .
} 
airspace unconnected with the use of land is inconceivable." 77 The court then reasoned that any use of airspace that actually damages the land or interferes with the possession or beneficial use of the land would be a trespass, but that "any claim of the landowner beyond this cannot find precedent in law nor support in reason." ${ }^{78}$ Because the plaintiffs did not show actual damages, the court denied both money damages and injunctive relief. ${ }^{79}$

The opinion that ownership of airspace rights "extended to the periphery of the universe" was laid to rest at the national level by the Supreme Court in 1946 in the case of United States v. Causby ${ }^{80}$ The Court concluded that the United States, by conducting nearly continuous, low-level flights of its military planes over a commercial chicken farm, made the property unusable for that purpose.$^{81}$ As such, these low-level flights amounted to a taking of an air easement for which compensation had to be paid to the farmer. ${ }^{82}$ Even though there was no actual physical invasion of the property, the court stated that the low-level flying was "an intrusion so immediate and direct" as to deprive the farmer of his use and enjoyment of the property, and dispossess him of his ability to continue to use the property as a commercial chicken farm. ${ }^{83}$ The Court distinguished a landowner's protectable property interest immediately above the surface of land from the "public highway" in the higher regions of airspace. ${ }^{84}$ The Court recognized that to have full use and enjoyment of one's land, a landowner "must have exclusive control of the immediate reaches of the enveloping atmosphere," lest the construction of buildings or planting of trees be precluded. ${ }^{85}$ Therefore, a surface owner owns at least as much airspace above the ground as the owner "can occupy or use in connection with the land." 86 Furthermore, intrusion into that airspace by an airplane or structure, even if it does not touch the ground, "is as much an

77. Id. (responding to plaintiffs' argument that they were entitled to absolute title to all airspace to such height as may become useful).

78. Id. at 758 .

79. Id. at 759 .

80. Causby, 328 U.S. at 260-61 ("It is ancient doctrine that a common-law ownership of the land extended to the periphery of the universe-Cujus est solum est usque ad coelum." (citing 1 COKE, InstituTES, ch. 1, §1(4a) (19th ed. 1832); 2 BlaCKSTONE, COMMENTARIES *18 (Lewis ed., 1902); 3 Kent, COMMENTARIES *621 (Gould ed., 1896))).

81. Causby, 328 U.S. at 259.

82. Id.

83. Id. at 265 .

84. Id. at 261-62.

85. Id. at 264 .

86. Id. 
appropriation of the use of land as a more conventional entry upon it." ${ }^{\prime 87}$ Thus, an airplane may fly over private property without being subject to liability so long as it is not at such a low altitude as to interfere with a "then existing use to which the land or water, or the space over the land or water, is put by the owner. $"{ }^{88}$ In reaching its decision, the Causby court stated that the ad coelum doctrine "has no place in the modern world." 89 The Court explained that airplanes are "part of the modern environment and life," the inconveniences it causes are not normally compensable under the Fifth Amendment, and the airspace (apart from that immediately above the land) is part of the "public domain." 90

Causby established a precedent that allows trespass and takings claims related to airspace use to prevail only in those circumstances where there was "a direct and immediate interference with the enjoyment and use of land." 11 Courts have looked to Causby and other airspace cases when deciding subsurface property rights cases; however, case law involving subsurface property rights is much broader and complicated than the body of airspace case law. The complication primarily arises from several attributes of subsurface rights that fundamentally distinguish them from airspace rights. ${ }^{92}$

The first distinction is that unlike airspace rights, subsurface rights have been severed, conveyed, bought, sold, used, and developed by private parties and federal, state, and local governments since at least the mid-1800s and perhaps before. This has resulted in ownership, use, and exploitation of the subsurface in a manner far more diverse and tangible than ever existed for airspace rights.

A second distinction is that the airspace cases addressed a single and very compelling "public interest" — national air travel — competing against surface interests. By contrast, in cases involving subsurface rights, the surface owner's rights often clash with multiple competing uses, such as oil and gas development, underground natural gas storage, groundwater production, underground storage of fresh water, and underground injection of fluid wastes. Moreover, all of these competing uses are subject to a federal or state regulatory system designed to promote each activity in the public interest.

87. Id.

88. Id. at 266 .

89. Id. at 261 .

90. Id. at 266 .

91. Id. at 264-66 ("The superadjacent airspace at this low altitude is so close to the land that continuous invasions of it affect the use of the surface land itself.").

92. Klass \& Wilson, supra note 3 , at $388-89$. 
A third and final distinction is Congress' declaration that "airspace shall be subject to a public right of freedom of interstate and foreign air navigation." ${ }^{93}$ This singularly defined public benefit of the skies contrasts with the long history of subsurface rights being bought, sold, and privatized by the federal government, the states, and private parties for numerous and varied commercial and industrial purposes.

Thus, the judicial and legislative precedent that limited the protection of private property rights in airspace may not be entirely instructive in the context of subsurface property rights in general and subsurface pore-space rights in particular. Indeed, in addressing trespass to land, the Second Restatement of Torts makes no express distinction between surface trespass and harmless subsurface intrusions. ${ }^{94}$ The Second Restatement expressly states that "a trespass may be committed on, beneath, or above the surface of the earth." 95 The only exception to this broad categorization relates to airspace intrusions ${ }^{96}$ by aircraft that are beyond the immediate reaches of the surface of the earth. ${ }^{97}$

Section 158, the principal Restatement provision pertaining to intentional trespasses, states:

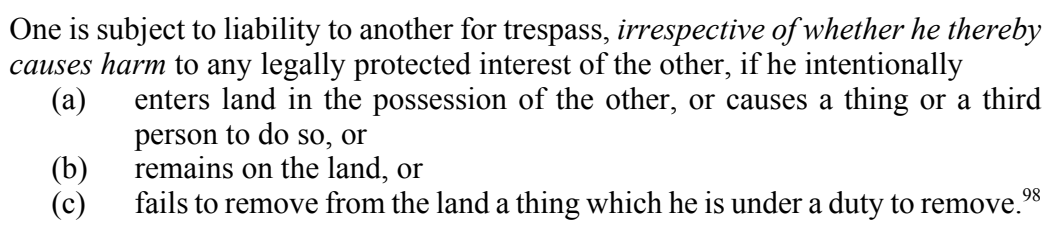

Under the Restatement, an actionable trespass occurs upon any intrusion that "enters land" in possession of another. ${ }^{99}$ The Restatement uses the word "intrusion" to emphasize that a property owner has a right to exclusive

93. See 49 U.S.C. $§ 180$ (1946) (repealed 1958).

94. The focus of Anderson II, supra note 3, is to criticize the Second Restatement, to illustrate that it no longer reflects the weight of case law, and to call upon the American Law Institute to rewrite trespass law to reflect modern case law that limits subsurface trespass claims to situations where a subsurface intrusion causes actual and substantial damages.

95. RESTATEMENT (SECOND) OF TORTS § 159 (1965).

96. Id.

97. Id. cmt. g. Though this exception would technically apply to any airspace, it more generally applies to the airspace extending upward beyond the immediate reaches of the surface, as aircraft rarely come within the useable reaches of most land. In its seminal Causby decision, the court granted relief to a chicken farmer who suffered actual harm resulting from low-flying aircraft. United States v. Causby, 328 U.S. 256, 266-67 (1946).

98. RESTATEMENT (SECOND) OF TORTS $§ 158$ (1965) (emphasis added).

99. Id. cmt. b. 
possession and enjoyment of land and that unprivileged presence of any person or thing amounts to an invasion of that interest. ${ }^{100}$

The Restatement expressly addresses intrusions upon, beneath, and above the surface of the land:

(1) Except as stated in Subsection (2), a trespass may be committed on, beneath, or above the surface of the earth.

(2) Flight by aircraft in the air space above the land of another is a trespass if, but only if,
(a) it enters into the immediate reaches of the air space next to the land, and
(b) it interferes substantially with the other's use and enjoyment of his land. ${ }^{101}$

Notice that the Restatement offers no provision comparable to Subsection (2), dealing with airspace, regarding subsurface trespass. Further, the Restatement offers no distinction between deep and shallow subsurface intrusions, thus extending its expansive scope of liability to include any subsurface activity, regardless of depth. ${ }^{102}$

In support, the ALI offers a list of older cases. ${ }^{103}$ The most familiar deal with caves: Edwards v. Lee ${ }^{104}$ and Marengo Cave Co. v. Ross. ${ }^{105}$ In each instance, the court treated intrusions into the cave as a trespass, although scholars have been critical. ${ }^{106}$ And scholars, addressing tunneling cases that do not affect the value of the land, argue that tunneling should not be regarded as a trespass at all. ${ }^{107}$

100. Id. cmt. c.

101. ReSTATEMENT (SECOND) OF TORTS $§ 159$ (1965).

102. Id. cmt. e. ("Trespass beneath the surface may be committed by ... any ... unprivileged entry on the land beneath the surface.").

103. City of Chicago v. Troy Laundry Mach. Co., 162 F. 678 (7th Cir. 1908) (construing Illinois law); Maye v. Yappen, 23 Cal. 306 (1863); Wachstein v. Christopher, 57 S.E. 511 (Ga. 1907); Mamer v. Lussem, 65 Ill. 484 (1872); Milton v. Puffer, 93 N.E. 634 (Mass. 1911); Buskirk v. Strickland, 11 N.W. 210 (Mich. 1882); National Copper Co. v. Minnesota Mining Co., 123 N.W. 781 (Mich. 1885); Huber v. Portland Gas \& Coke Co., 274 P. 509 (Or. 1929).

104. 19 S.W.2d 992 (1929).

105. 10 N.E.2d 917 (Ind. 1937).

106. W. Page Keeton et al., Prosser and Keeton on the Law of Torts $§ 13$ (5th ed. 1984) (stating that because the surface owner had no practical access to the caves, either now or in the future, the decision is "dog-in-the-manger law, and can only be characterized as a very bad one.") (citing Edwards v. Lee, 19 S.W.2d 992 (Ky. Ct. App. 1929) and Marengo Cave Co., 10 N.E.2d 917).

107. DAN B. DOBBS, THE LAW OF TORTS $\S 55$ (2000). In support of this argument, see, e.g., Application of Gillespie, 17 N.Y.S.2d 560 (N.Y. Gen. Term 1940) and Boehringer v. Montalto, 254 N.Y.S. 276 (N.Y. Spec. Term 1931). 
While the Restatement reflects the common law's tendency to afford great protection to a landowner seeking to maintain the right of exclusive possession and enjoyment, ${ }^{108}$ some limitations must exist, ${ }^{109}$ especially where an intruder's use of property does not impair the owner's possession and enjoyment. ${ }^{110}$ Yet, without providing exceptions for harmless subsurface invasions, the Restatement provides a cause of action to redress a host of subsurface activities that do no actual or substantial harm to the possessor's rights of exclusive possession and enjoyment.

The Restatement should adopt an exception for deep subsurface intrusions similar to the exception it already recognized for aircraft. The Restatement exempts from liability those subsurface invasions that occur beyond the immediate reaches of the surface and that cause no harm. Although some subsurface invasions may have a more permanent and constant presence than airplane fly-overs, the occurrence of actual or substantial damage properly supports treating the two invasions similarly. Moreover, such a change would bring the Restatement more in line with the clear trend of modern case law. ${ }^{111}$

\section{CONTEMPORARY COMMON LAW AND STATUTORY MODELS FOR ACQUIRING THE RIGHT TO USE PORE SPACE FOR INDUSTRIAL AND COMMERCIAL UNDERGROUND FLUID INJECTION ACTIVITIES}

Modern case law generally treats surface intrusions and subsurface intrusions differently. Regarding traditional surface trespass, Loretto $v$. Teleprompter Manhattan CATV Corp. is perhaps the seminal case in which the Supreme Court addressed the issue of permanent physical occupation of a surface owner's property. ${ }^{112}$ The specific issue before the Court was whether a New York law requiring a landlord to permit the installation of a cable company's cables on rental properties to furnish cable television services to

108. See KeETON ET AL., supra note 106, at $\S 13$ ("It seems more reasonable to limit the recovery without proof of damage to cases of intentional invasion, where the trespass action may serve an important purpose in determining and vindicating the right to exclusive possession of the property.").

109. See e.g., Taco Cabana, Inc. v. Exxon Corp., 5 S.W.3d 773, 780 (Tex. App. 1999) (rejecting plaintiff's theory of trespass under Restatement section 158, which requires no showing of harm where subsurface contamination levels did not exceed thresholds established in the state water code).

110. See Chance v. BP Chemicals, Inc. 670 N.E.2d 985, 992 (Ohio 1996) ("Just as a property owner must accept some limitations on the ownership rights extending above the surface of the property, we find that there are also limitations on property owners' subsurface rights.").

111. For further discussion, see Anderson II, supra note 3.

112. 458 U.S. 419 (U.S. 1982) (Loretto I). 
tenants rises to the level of a taking without just compensation. ${ }^{113}$ The Supreme Court ruled that the state statute amounted to a taking of a portion of the plaintiff's property - around one and one-half cubic feet on the outside of the rental building, to be precise - for which she was entitled to just compensation under the Fifth Amendment. ${ }^{114}$ The Court found that, to the extent the government permanently occupies property or grants a third party the right to do so, it effectively destroys the right to "possess, use, and dispose" of property and will amount to a taking in any such circumstance. ${ }^{115}$ The Court further concluded that, in applying this per se taking rule for physical occupations, the size of the area occupied is irrelevant, as is whether the plaintiff previously occupied the space in question. ${ }^{116}$ The Court relied on Causby to support the proposition that "[a]n owner is entitled to the absolute and undisturbed possession of every part of his premises, including the space above, as much as a mine beneath." 117 On remand, however, the Court of Appeals of New York ruled that the amount of compensation awarded could be nominal and predetermined (in Loretto II, a one-time \$1 payment), ${ }^{118}$ provided that property owners had a mechanism available through which to seek more compensation by proving special circumstances. ${ }^{119}$

There is undeniable language in Loretto I to support the position that any and all physical occupation of subsurface pore space would be a taking, particularly the declaration that a plaintiff need not have previously occupied the space in question in order for a taking of private property without just compensation to be found. ${ }^{120}$ There is also the statement that there is a right of "undisturbed possession" of every part of a surface parcel, including the "space above" and the "mine beneath." 121 On the other hand, the Loretto I court relied heavily on Causby in supporting its ruling. Causby clearly abridged property interests in the high airspace (i.e., the "public highway"), yet continued to protect those property interests in the airspace that are necessary

113. Id. at 421 .

114. Id. at 441 .

115. Id. at 435 (quoting United States v. Gen. Motors Corp., 323 U.S. 373, 378 (1945)).

116. $I d$. at 438 n. 16 .

117. Id. at 437 n. 13 .

118. Loretto I, 458 U.S. at 423-24.

119. That is unless the property owner meets the burden of proof for establishing that the diminution in value of the property was materially different than the general assumption, and is therefore entitled to receive greater compensation. Loretto v. Teleprompter Manhattan CATV Corp., 446 N.E.2d 428, 432-33 (N.Y. 1983) (Loretto II).

120. Loretto I, 458 U.S. at 437 n.13 (quoting United States v. Causby, 328 U.S. 256, 256 n.10 (1946)). 121. Id. 
to enjoy unencumbered use of surface property. ${ }^{122}$ Thus, it is reasonable to assume that property interests in the subsurface that are necessary to the use of the surface or are currently being exploited for commercial or industrial uses would be protected under Causby. However, Causby can also be interpreted to support the proposition that not all subsurface property is afforded protection from intrusions - particularly property that is far beneath the surface of the earth and generally inaccessible to all but a small proportion of landowners. Even so, any effort to use Causby to support a restricted view of subsurface property rights must account for the fact that, unlike airspace rights, there is a long and established history of subsurface rights having been bought, sold, used, and developed by private parties.

While no case specifically related to the encroachment of subsurface property rights has yet been argued before the Supreme Court, state and other federal courts have ruled on this issue in the context of various commercial and industrial subsurface injection activities that gave rise to both takings and trespass claims. These courts have a history of balancing competing interests in the subsurface and have placed great weight on the public interest and regulatory approval associated with certain activities. Specifically, courts have given surface and mineral owners only limited protection against subsurface intrusions resulting from the migration of fluids injected underground.

Courts have addressed the issue of subsurface trespass in the context of five subsurface injection activities that are frequently considered analogous to geological sequestration of $\mathrm{CO}_{2}$ : (1) licensed subsurface storage of natural gas; (2) licensed subsurface injection and disposal of fluid waste; (3) stateauthorized subsurface injections to enhance hydrocarbon recovery (unitization); ${ }^{123}$ (4) injections of fluids and proppants to facilitate petroleum production (hydraulic fracturing); and (5) subsurface storage and recharge of fresh water. ${ }^{124}$ In each of these groups of cases, the courts balanced the need

122. Causby, 328 U.S. at 266.

123. This process can cause migration of the injected fluid, or the native oil and gas sought to be produced, into a neighboring production field and inhibit another producer's ability to recover oil or gas resources.

124. See Wilson \& de Figueiredo, supra note 3, at 10119-21; Anderson I, supra note 3, at 97-98; Owen L. Anderson, Subsurface "Trespass": A Man's Subsurface is Not His Castle, 49 WASHBURN L.J. 247, 255-81 (2010) [hereinafter Anderson III]; Klass \& Wilson, supra note 3, at 363. Cases involving ownership rights to oil, gas, coal, ground water, and other subsurface natural resources are less instructive than cases involving subsurface waste injection, natural gas storage, enhanced petroleum recovery and unitization, hydraulic fracturing, and underground water storage and recharge. The reason is that oil, gas, coal, ground water, etc. involve disputes over ownership of a valuable commodity found within the subsurface, whereas the latter set of cases deal with disputes over the use of the subsurface strata itself. 
to protect a landowner's right to exclusive possession and enjoyment with the public-interest need of facilitating valuable enterprises that meet important societal needs. The great weight of case law, although not large in volume, supports the proposition that takings and trespass claims will not stand absent actual and substantial damages. However, the case law is neither entirely unified nor coherent.

In the cases involving the subsurface injection of fluids for waste disposal, enhanced hydrocarbon recovery, hydraulic fracturing, and underground water storage, the courts have consistently modified the ad coelum doctrine, and limited the ability of surface owners and mineral owners to recover money damages for trespass or for a taking resulting from government-authorized use of subsurface pore space. Regarding subsurface natural gas storage, project developers have generally proceeded under the Natural Gas Act to acquire subsurface property by eminent domain, thus implicitly acknowledging (or at least not expressly challenging) that the use of pore space requires compensation; however, where eminent domain was not utilized, no natural gas storage case has awarded damages for trespass. Courts and lawmakers will undoubtedly look to these cases for guidance to determine whether the use of deep geologic pore space for permanent sequestration of $\mathrm{CO}_{2}$ without compensation rises to the level of a trespass or unlawful taking.

\subsection{Natural Gas Storage Model}

Natural gas is frequently injected into the subsurface for temporary storage. If the injected gas migrates beneath neighboring lands, then a technical trespass has occurred. Trespass issues arising in the gas storage context offer insight about how courts may analyze subsurface invasions of pore space in the geologic $\mathrm{CO}_{2}$ sequestration context. In both contexts, whether a subsurface invasion caused by the injected fluid is an actionable trespass or rises to the level of an unlawful taking of private property will depend on public policy goals and the facts of the particular case at bar. Of course, gas storage and geologic sequestration of $\mathrm{CO}_{2}$ are factually distinct: gas storage is an ongoing operation, involving an ongoing cycle of injections and withdrawals of gas, whereas $\mathrm{CO}_{2}$ sequestration involves injection for permanent disposal. Additionally, gas is a valuable commodity, while $\mathrm{CO}_{2}$ is essentially a waste product. Moreover, a geologic sequestration reservoir will eventually reach its maximum capacity, at which time $\mathrm{CO}_{2}$ injection will cease; the cyclical injection and withdrawal of natural gas for storage could continue indefinitely. These factual distinctions, however, do not render gas storage law useless in terms of signaling how legislatures and the courts will 
handle the use of subsurface pore space as it relates to geologic sequestration of $\mathrm{CO}_{2}$.

In most jurisdictions, pipeline companies and gas utilities possess the state-authorized right of eminent domain and often acquire storage rights to the entire subsurface reservoir using such authority. Under the Natural Gas Act and judicial decisions interpreting the Act, natural gas companies that obtain a "certificate of public convenience" from the Federal Energy Regulatory Commission (FERC) have the power of eminent domain to condemn private property for the purpose of constructing underground natural gas storage facilities. ${ }^{125}$ Not surprisingly, when property is condemned, courts have been forced to resolve disputes over ownership and valuation of the pore space in which the natural gas is stored.

Two types of disputes often arise in natural gas storage cases. The first is where a natural gas company obtains a certificate of public convenience from FERC and then attempts to contract with the surface owner to obtain the necessary storage rights and, if they are unable to reach agreement, then exercises the power of eminent domain to take the subsurface within the area covered by the certificate. In this situation, disputes may arise over the valuation of the storage space, but it is well settled that compensation must be paid when the exclusive right to protect the storage strata by condemning all other exploitation of the strata and its contents is acquired by the natural gas storage company. The second type of dispute is where the natural gas company fails to obtain all of the storage rights for the subsurface area that the stored gas actually occupies, creating a "window," usually along the edge of the storage field. In this case, the owner of a window property may sue for trespass or produce the stored gas. In response, the gas company may file a condemnation action to prevent the owner from either withdrawing the company's stored gas or damaging the integrity of the storage reservoir. At that point, the window owner may then counterclaim for trespass, seek an injunction, and claim compensatory and perhaps even punitive damages. ${ }^{126}$

125. See 15 U.S.C. § 717f(h); Colum. Gas Transmission Corp. v. Exclusive Gas Easement, 776 F.2d 125, 128 (6th Cir. 1985); Steven D. McGrew, Note, Selected Issues in Federal Condemnations for UnderGround Natural Gas Storage Rights: Valuation Methods, Inverse Condemnation, and Trespass, 51 CASE W. RES. L. REV. 131 (2000).

126. See McGrew, supra note 125 , at 179-80 (discussing claims for punitive damages in subsurface trespass case); Alexandra B. Klass, Punitive Damages and Valuing Harm, 92 MINN. L. REV. 83, 105-07 (2007) (discussing available of punitive damages in surface trespass cases). To the extent a property is in split estate and the natural gas storage interferes with the mineral rights owner's ability to develop the oil or gas, the mineral rights owner may also have a claim for trespass or a right to just compensation resulting from condemnation. 
The Natural Gas Act, and judicial decisions interpreting the Act, recognize that an exclusive right to use pore space for natural gas storage must be acquired either by voluntary contract or forced condemnation.

Even so, the body of authority for natural gas storage should not be construed to indicate that the unauthorized and uncompensated use of pore space for GCS will constitute an actionable subsurface trespass or unlawful taking in all circumstances. Historically, the motivation for condemning property and compensating surface and mineral owners in the context of natural gas storage has more to do with protecting the integrity of the storage field and retaining exclusive control of the stored natural gas than the value of the subsurface pore space being utilized for storage. In Hammonds v. Central Kentucky Natural Gas Co., the court impoliticly reasoned that natural gas injected for storage was released back to nature - in essence, abandoned. ${ }^{127}$ Because the gas was abandoned, the gas had no owner. ${ }^{128}$ Comparing injected gas to captured wild animals that were returned to nature, the court found that no trespass occurred when the released gas migrated to neighboring property. ${ }^{129}$ The court further ruled that when the gas was returned to nature, it became "subject to appropriation by the first person" to capture the gas. ${ }^{130}$ Thus, the only way the storage company could protect its interest in the injected gas was to acquire the exclusive right to explore for and produce the gas it reinjected into the subsurface.

The Hammonds Doctrine, as it is known, has been widely criticized and rejected by numerous courts, but it arguably influenced the trend among natural gas storage companies to often include both surface owners and mineral owners in voluntary negotiations or, if necessary, as parties to condemnation actions to develop natural gas storage fields, thus providing compensation to both sets of property owners. ${ }^{131}$ Moreover, as a practical matter, Hammonds has not been overruled in Kentucky. In Texas American Energy Corp. v. Citizens Fidelity Bank \& Trust Co, the court reasoned that:

in those instances when previously extracted oil and gas is subsequently stored in underground reservoirs capable of being defined with certainty and the integrity of

127. 75 S.W.2d 204, 205-06 (Ky. 1934).

128. $I d$.

129. Id. at 206.

130. $I d$.

131. See Stamm, supra note 47, at 164-74; Lone Star Gas Co. v. Murchison, 353 S.W.2d 870, 879-80 (Tex. Civ. App. 1962); White v. N.Y. St. Natural Gas Corp., 190 F. Supp. 342 (E.D. Pa. 1960); Humble Oil \& Ref. v. West, 508 S.W.2d 812, 817 (Tex. 1974); ANR Pipeline Co. v. 60 Aces of Land, 418 F. Supp. 2d 933, 940 (W.D. Mich. 2006). 
said reservoirs is capable of being maintained, title to such oil or gas is not lost and said minerals do not become subject to the rights of the owners of the surface above the storage fields. ${ }^{132}$

On its face, the opinion may seem to reject the previous holding in Hammonds. However, the language about maintaining the integrity of the reservoir suggests that the injector must control all the rights of access to the reinjected gas throughout the full extent of the storage reservoir (the facts in Texas American) to maintain title to the stored gas; therefore Hammonds was not overruled because the injector in that case did not have full control of the reservoir.

Kansas courts have also been reluctant to dismiss the Hammonds doctrine in the following circumstance: "where a natural gas public utility was not involved, where no certificate authorizing an underground [natural gas] storage facility had been issued by the Kansas Corporation Commission, and where the defendant [landowner] had used the property of an adjoining landowner for gas storage without authorization or consent." ${ }^{133}$ Such was the circumstance in Anderson v. Beech Aircraft. ${ }^{134}$ In Beech Aircraft, the Supreme Court of Kansas was reluctant to find a trespass occurred because the defendant, as the owner and injector of non-native natural gas, lost title when the non-native gas was commingled with natural gas in a reservoir that extended underneath adjoining property. The court concluded that the neighboring landowner was free to produce the non-native gas and thus suffered no damages. ${ }^{135}$

Certain jurisdictions have rejected the Hammonds doctrine outright. In Lone Star Gas Co. v. Murchison, ${ }^{136}$ a Texas appellate court shrewdly rejected the Hammonds line of reasoning, ruling that natural gas injected for storage is

132. 736 S.W.2d 25, 28 (Ky. 1987).

133. Anderson v. Beech Aircraft Corp. 699 P.2d 1023, 1032 (Kan. 1985); see also Union Gas Sys., Inc. v. Carnahan, 774 P.2d 962, 967 (Kan. 1989). These cases were distinguished in Reese Exploration, Inc. v. Williams Natural Gas Co., 983 F.2d 1514, 1523 (10th Cir. 1993). Parties having the power of eminent domain may protect their rights by securing a state certificate and by condemning the reservoir, and such parties are further protected from the rule of capture if they can prove by a preponderance of the evidence that injected gas had migrated to adjoining property or to a stratum that has not been condemned. See KAN. STAT. ANN. §§ 55-1205 to 1210 (2007); see Williams Natural Gas Co. v. Supra Energy, Inc., 931 P.2d 7 (Kan. 1997); Union Gas, 774 P.2d at 967. For the meaning of "adjoining," see Northern Natural Gas Co. v. Nash Oil \& Gas Inc., No. 04-1295-JTM, 2005 U.S. Dist. LEXIS 10181, at *7 (D. Kan. May 16, 2005). If gas migrates into another stratum, further condemnation may be pursued, but landowners' damages for the pre-condemnation trespass and unjust enrichment are measured by the fair rental value of such stratum. Beck v. Natural Gas Co., 170 F.3d 1018, 1024 (10th Cir. 1999).

134. 699 P.2d 1023 (Kan. 1985).

135. Id. at 1032 .

136. 353 S.W.2d 870 (Tex. App. 1962). 
not abandoned, but remains the personal property of the injecting party, and as such, is not subject to capture by neighboring landowners even if the gas migrates beneath neighboring tracts. ${ }^{137}$ The Lone Star case did not, however, squarely address the question of whether the invasion of stored gas is compensable, because no actionable case for trespass was presented by the neighboring landowner. The court explained:

\footnotetext{
Appellees expend a great deal of space in their brief to the argument that appellant has trespassed upon their property. The status of this record is such, however, that we must, as Ulysses 'lash ourselves to the mast and resist Siren's songs' of trespass, or similar contention. This, for the simple reason that no action seeking redress or claimed trespass is here presented. ${ }^{138}$
}

An Oklahoma statute, which permits natural gas companies to obtain storage rights by condemnation, established that injected gas remains the property of the injector, even if gas migrates beneath other lands. ${ }^{139}$ Under the statute, retention of ownership to stored gas is contingent upon the injector proving migration as well as compensating the owner of the invaded stratum. ${ }^{140}$ In Oklahoma Natural Gas Co. v. Mahan \& Rowsey, Inc., ${ }^{141}$ the United States Court of Appeals for the Tenth Circuit effectively upheld the Oklahoma statute when it implicitly concluded that the storage operator retained title to injected gas that migrated to neighboring lands. ${ }^{142}$ In this case, however, ownership of the injected gas was easily determinable because the stored gas was confined to an identifiable and well-defined formation, plus, due to helium content and a lack of certain organic compounds, the stored gas was distinguishable from native gas in the area. ${ }^{143}$

In ANR Pipeline Co. v. 60 Acres of Land,${ }^{144}$ the U.S. District Court for the Western District of Michigan signaled its intention to patently reject the Hammonds doctrine. Specifically, the court stated: "[i]njected gas which has previously been produced, reduced to possession, and then reinjected into the ground is not subject to the rule of capture. Once severed from the realty, gas becomes personal property, and title to that property is not lost when it is

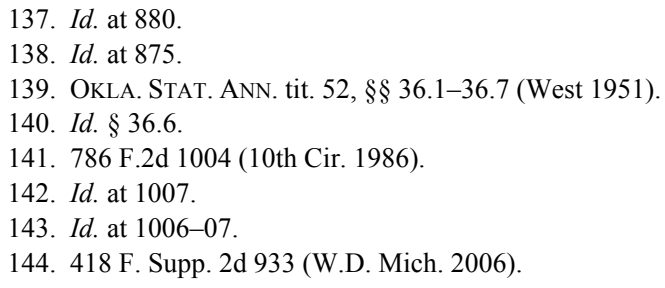


injected into underground gas storage reservoirs. ${ }^{145}$ Accordingly, if injected gas moves across boundaries, there may be a trespass." ${ }^{.146}$ Moreover, intrusions onto private property caused by the actions of a gas storage company with condemnation authority may be the basis of an inverse condemnation claim. ${ }^{147}$ The court concluded, however, that migration of native gas (caused by the injection of non-native gas) beneath the defendant's property did not amount to an inverse condemnation because ANR's actions did not cause "any diminution in the value of [defendant's] land, any serious injury to their property, or any interference with the use of their property." 148 The court explained that, even if native gas beneath the defendants' property had been impressed into public service, this alone is insufficient to support an action for an unjust taking. ${ }^{149}$ "An inverse condemnation claim requires more than a showing that private property has been put to some public use." ${ }^{150}$ Citing two earlier cases decided by the Michigan Court of Appeals, one of which was relied upon by the defendants, the court asserted that "taking property for a public use must be accompanied by harm before it will be cognizable as a taking subject to an inverse condemnation claim." 151

At least two courts submitted that state trespass claims are preempted by the Natural Gas Act, and therefore, the only remedy available is an action in inverse condemnation. In the first case, Columbia Gas Transmission Corp. v. An Exclusive Natural Gas Storage Easement, ${ }^{152}$ Columbia Gas brought an action to condemn an underground natural gas storage easement beneath the property of a neighboring landowner. ${ }^{153}$ As Columbia Gas' storage of gas under the landowner's property predated the filing of the condemnation action, the landowners counterclaimed, seeking compensatory and punitive damages for trespass. ${ }^{154}$ The United States District Court for the Northern District of Ohio, reversing a position it previously took on similar issues, ${ }^{155}$ concluded

145. Id. at 940; White v. N.Y. St. Nat. Gas. Corp., 190 F. Supp. 342, 347 (W.D. Pa. 1960).

146. ANR Pipeline, 418 F. Supp. $2 \mathrm{~d}$ at 940.

147. Id. at 939 .

148. Id. at 942 .

149. Id. at 941-42.

150. Id. at 941 .

151. Id. (citing Fox v. Ogemaw County, 528 N.W.2d 210 (Mich. Ct. App. 1995); Jones v. East Lansing-Meridian Water \& Sewer Auth., 296 N.W.2d 202 (Mich. Ct. App. 1980)).

152. 747 F. Supp. 401 (N.D. Ohio 1990).

153. Id. at 402 .

154. Id.

155. Bowman v. Columbia Gas Transmission Corp., 850 F.2d 692 (6th Cir. 1988) (affirming the United States District Court for the Northern District of Ohio's decision to allow, over Columbia's objection, a similar trespass action to be prosecuted and allowing the jury to assess punitive damages). 
that "the landowner's remedies with respect to the taking of his property by the United States Government or by a private corporation authorized to exercise the power of eminent domain are controlled and limited by federal substantive law." "The conclusion that Ohio law regarding the taking of property for public use is not applicable because it is preempted by federal law is dispositive of [the landowner's] counterclaim for trespass and punitive damages. It will not be allowed to proceed." 157 The landowners were, however, granted leave to file an amended counterclaim seeking compensatory damages for inverse condemnation. ${ }^{158}$ The Columbia Gas court also held that the landowner bore the burden of establishing actual damages to prevail on an inverse condemnation claim. ${ }^{159}$ The court went even further to suggest that the natural storage operator has no incentive to condemn property into which its gas has migrated unless the integrity of the company's storage field is threatened. ${ }^{160}$

In the second case, Mississippi River Transmission Corp. v. Tabor, ${ }^{161}$ the Fifth Circuit rejected on two separate grounds the property owner's trespass claims against the gas company for its purported use of his property as a gas storage reservoir before it was legally expropriated. ${ }^{162}$ First, the court of appeals opined that the landowner had failed to prove that any trespass on his particular interest in the property had occurred. ${ }^{163}$ Second, the court of appeals concluded that, even if a trespass had occurred, the property owner was entitled to no additional compensation for that trespass in addition to the condemnation award. ${ }^{164}$ As the Fifth Circuit explained,

Once the Louisiana Department of Conservation issued its order authorizing the construction of the [storage facility], [natural gas] production ... within the storage area was forever halted; Tabor Jr.'s sole right as a mineral servitude owner from that point forward, therefore, was the right to have his mineral interests legally expropriated and to receive just compensation for the recoverable reserves in the reservoir. $^{165}$ at 404 .

156. Columbia Gas Transmission Corp. v. An Exclusive Natural Gas Storage Easement, 747 F. Supp.

157. Id.

158. Id. at 406 .

159. Id. at 405 .

160. Id.

161. 757 F.2d 662 (5th Cir. 1985)

162. Id. at 676.

163. Id. at $672-73$.

164. Id. at 673 .

165. Id. 
The measure of just and adequate compensation to which Tabor Jr. is entitled "is to be estimated by the same standard whether the property taken is formally expropriated in accordance with law or appropriated by the condemning authority so long as it is intentionally taken for a public use." 166

The notion that state trespass claims are preempted by the Natural Gas Act has been criticized by legal commentators and rejected by the United States District Court for the District of Kansas. ${ }^{167}$ In Humphries v. Williams Natural Gas Company, ${ }^{168}$ the district court held that a condemnation action under the Natural Gas Act “does not preempt all of Humphries' pre-condemnation state law claims. Humphries may seek damages on his pre-condemnation state law claims against the defendant to the extent that those damages are separate and distinct from the compensation he may receive in the condemnation proceedings."169

While the natural gas storage case law is instructive of how courts may treat the use of subsurface pore space in the context of geologic $\mathrm{CO}_{2}$ sequestration, the number of opinions available for review is sparse. Moreover, most judicial decisions that address subsurface invasions caused by the storage of natural gas either: (1) focus on ownership of the stored gas, not the invasion itself; or (2) treat trespass allegations as actions in inverse condemnation ${ }^{170}$ because gas storage rights may be acquired by eminent domain. ${ }^{171}$ Thus, any attempt to distill from this body of jurisprudence definitive legal principles for addressing the use of pore space in the context of geologic $\mathrm{CO}_{2}$ sequestration is, at best, of limited utility; at its worst, conclusions drawn from such an analysis could lead, and have led, lawmakers dangerously astray. Arguably, the practice of compensating property owners to use subsurface pore space for storing natural gas developed as much out of industry custom and the need to maintain possession and control of injected gas, as it has from adherence to legal and regulatory requirements. Because natural gas is a valuable

166. Id. (quoting Gray v. State through Department of Highways, 202 So. 2d 24, 26 (La. 1976) for its application of Article 1, $\S 4$ of the Louisiana Constitution of 1974 (previously Article 1, 22 of the Louisiana Constitution of 1921, and LA. Rev. STAT. ANN. § 19:9 (1979)).

167. See Humphries v. Williams Natural Gas Co., 48 F. Supp. 2d 1276 (D. Kan. 1999); McGrew, supra note 125, at 172-74; George H. Genzel, Annotation, Award of, or Pending Proceedings for, Compensation for Property Condemned, as Precluding Action for Damages Arising From Prior Trespasses Upon It, 33 A.L.R. 3d 1132 (1971).

168. 48 F. Supp. 2d 1276 (D. Kan. 1999).

169. Id. at 1283 .

170. See, e.g., Columbia Gas Transmission Corp. v. An Exclusive Natural Gas Storage Easement, 747 F. Supp. 401, 405 (N.D. Ohio 1990).

171. See, e.g., Pac. Gas \& Elec. Co. v. Zuckerman, 234 Cal. Rptr. 630 (Cal. Ct. App. 1987); Iroquois Gas Corp. v. Gernatt, 281 N.Y.S.2d 896 (N.Y. App. Div. 1967). 
commodity that is stored only temporarily and then retrieved, and because underground storage of gas is an ongoing and valuable sector of the natural gas industry, a gas storage operator has the compelling motivation to compensate landowners for use for use of the storage space to ensure complete control of the storage reservoir and to protect against losing gas before it can be recovered and sold or consumed. In addition, because stored gas may be commingled with natural gas in a common reservoir, acquisition of clear storage rights by purchase or by eminent domain is highly desirable, if not essential, in some circumstances.

By contrast, GCS operators will not be concerned with maintaining the integrity of the sequestration field for the purpose controlling the injected $\mathrm{CO}_{2}$ so that it can be easily recovered at a later time to be traded and sold. Quite the contrary, the sole purpose of GCS is to keep $\mathrm{CO}_{2}$ underground and out of the atmosphere permanently. Moreover, the GCS operator will not necessarily be concerned that the $\mathrm{CO}_{2}$ may be commingled with other $\mathrm{CO}_{2}$, whether naturally occurring or injected. ${ }^{172}$ Thus, apart from assuring the long-term integrity of the storage reservoir, the migration of $\mathrm{CO}_{2}$ will be of no concern to the GCS storage operator.

Despite the important distinctions which can be readily drawn between natural gas storage and the permanent geologic sequestration of $\mathrm{CO}_{2}$, the Interstate Oil and Gas Compact Commission (IOGCC) issued a model statute for GCS based on existing state laws for natural gas storage. ${ }^{173}$ The IOGCC Model Statute recommends that the acquisition of property rights for GCS be undertaken in the same manner as for natural gas storage projects: "The Model General Rules and Regulations propose the required acquisition of these storage rights and contemplate's [sic] use of state natural gas storage eminent domain powers or oil and gas unitization processes to gain control of the entire storage reservoir." ${ }^{174}$ On first impression, this might seem to be a logical extension of an established regulatory framework. However, the potentially very large scale of property rights necessary for GCS, coupled with the perceived urgency to develop commercial-scale GCS rapidly, could make the natural gas storage model unwieldy at best, unworkable at worst.

To facilitate the development of natural gas storage projects, many states adopted condemnation statutes, which allow gas storage companies to

172. An exception might be where commercial quantities of $\mathrm{CO}_{2}$ exist that might be suitable for production and use, such as for enhanced oil recovery, as is the case in the San Juan Basin of Southern Colorado and Northern New Mexico.

173. THE INTERSTATE OIL AND GAS COMPACT COMMISSION, supra note 9.

174. Id. at 11 . 
condemn rights in underground storage reservoirs. However, many of these states allow condemnation only in reservoirs where minerals can no longer be produced in commercial quantities. ${ }^{175}$ When a gas storage facility is developed and is later found to interfere with active mineral production operations, most state condemnation statutes are not designed to remedy the problem. ${ }^{176}$ Often times, the only solution may be to discontinue storage operations.

Of course, state condemnation statutes used to develop underground gas storage facilities do not currently address GCS. Legislation, either state or federal, is needed to provide condemnation authority for GCS. The IOGCC Model Statute provides such rights, but it does not authorize GCS in formations containing commercial quantities of oil, gas, or other valuable resources. The IOGCC Model Statute requires GCS project developers to identify and negotiate in good faith with all property owners "having property interests affected by the storage facility." 177 In addition, all property owners within one-half mile of the proposed project boundary must be notified by first-class mail and given an opportunity to participate in hearings. ${ }^{178}$ For a GCS project covering hundreds or thousands of square miles, with an equal number of affected landowners, this could be a very onerous task to be sure. Thus, the required statutory amendments, individual landowner negotiations, and subsequent condemnation proceedings required under the IOGCC Model Statute are not likely to foster the rapid deployment of large-scale GCS.

175. ARK. CODE ANN. § 15-72-604(a)(1) (West 2010) (disallowing condemnation if the formation is producing, or is capable of producing, in paying quantities through any known recovery method); CoLO. REV. STAT. ANN. § 34-64-104 (West 2010) (barring condemnation unless the formation is nonproductive of gas in commercial quantities under either primary or secondary recovery methods); 220 ILL. COMP. STAT. ANN. 15/2 (West 2010) (disallowing condemnation unless the formation is nonproductive of gas in commercial quantities under either primary or secondary recovery methods); MO. REV. STAT. $\$ 393.460$ (allowing condemnation of a formation for gas storage purposes unless the formation contains natural gas that may be produced in commercially paying quantities); MONT. CODE ANN. § 82-10-303(1)(b) (2009) (prohibiting gas-bearing formations from condemnation unless recoverable volumes of native gas have been produced, or the formation has greater value or utility as storage than for production of relatively small amounts of remaining native gas compared with original volumes); NEB. REV. STAT. § 57-605 (2010) (if any recoverable native gas remains, the use of a formation for storage must be determined to be in the public interest because the formation has greater value as storage facility than for production of remaining volumes of native gas); OKLA. STAT. ANN. tit. 52, § 36.3(b) (2010) (barring condemnation of a formation unless the volume of native gas originally in place is substantially depleted, and the formation has greater utility as a storage facility than for production of relatively small volumes of remaining gas); W. VA. CODE $\S 54-1-2(a)(3)$ (2010) (permitting condemnation of underground storage facilities when previous exploration has shown the formation has ceased to produce, or has been proved to be nonproductive of, gas in substantial quantities).

176. See, e.g., Anderson v. Beech Aircraft Corp., 699 P.2d 1023, 1026 (Kan. 1985).

177. The InTERStATE OIL AND GAS COMPACT COMMission, supra note 9, § 3(a)(2), at 33.

178. Id. $\S 5(\mathrm{~b})(3)$, at 42. 


\subsection{Enhanced Hydrocarbon Recovery, Field Unitization, and Hydraulic Fracturing Models}

For decades, oil and gas production companies have injected fluids (often water, natural gas, or $\mathrm{CO}_{2}$ ) into producing oil and gas reservoirs to enhance the ultimate recovery of hydrocarbons. This process, known as enhanced oil recovery (EOR) or secondary recovery, ${ }^{179}$ re-pressurizes or otherwise stimulates the reservoir and can significantly increase petroleum recovery. Trespass issues can arise when an EOR operator injects fluids into the subsurface of its own property and the fluid then invades the subsurface of neighboring property. Compensable damages can result when oil reserves on the invaded property are displaced or when the invasion makes recovery of such reserves more difficult or expensive. Judicial decisions addressing subsurface trespass allegations in the enhanced-recovery operations are mixed, but several cases suggest that a compensable trespass claim is less likely to succeed if a regulatory agency authorized the particular operation brought before the bench for trial.

Most enhanced-recovery operations take place in fields that have been "unitized" pursuant to state regulatory orders. With "field unitization," individual producing tracts are combined, with production being carried-out by a designated unit operator, while the costs and profits of the project are shared by owners of the unitized tracts on a "fair share" basis. In most states, the property rights of landowners in the unitized area are addressed by state unitization laws, which may allow the unit operator to proceed regardless of whether they are able to reach agreement with all landowners. Most states require agreement by a minimum percentage (ranging from $50 \%$ to $80 \%$ ) of ownership in a reservoir to authorize compulsory unitization. ${ }^{180}$ On the other hand, in Texas, only voluntary unitization is possible, although the state regulatory agency, the Texas Railroad Commission, still issues orders approving voluntary units. ${ }^{181}$ Even when unitization of the entire reservoir does not occur, regulatory officials may approve agreements creating a partially unitized field. In those circumstances, common law has evolved to protect unit

179. Traditional methods, such as water flooding, are usually called secondary recovery, while more advanced methods, such as $\mathrm{CO}_{2}$ injection, are called enhanced recovery and sometimes tertiary recovery. For simplicity, we will use the term enhanced oil recovery or EOR.

180. See, e.g., CAL. Pub. Res. Code $\S 3643$ (b) (West 2010) (allowing forced unitization if at least three-fourths of royalty interests and working interests agree to unitize).

181. See, e.g., 16 TEX. ADMIN. CODE $§ 3.40$ (West 2010). 
operators against trespass claims made by "hold-out" landowners who decline the opportunity to participate in the unit. This protection protects unit operators from trespass claims as well as from claims for excessive drainage of petroleum, and is grounded in the public's interest in efficient petroleum production. Allowing hold-outs within the unit area to sue for damages would defeat the state's goal of facilitating resource conservation through unitized production.

As with title issues, regulatory bodies have no general authority to authorize trespasses or other torts. However, an early Texas case suggests that regulatory orders may provide some protection. In Railroad Commission $v$. Manziel, ${ }^{182}$ the plaintiff landowners sought to set aside a commission order authorizing the operator of an adjacent tract to drill an exception-location well close to their tract to inject water for EOR. ${ }^{183}$ The exception well was permitted under the auspices of a commission-approved voluntary-unitization plan. ${ }^{184}$ The landowners sought to set aside the order on the ground that water injected at that location would inevitably cross ownership lines, resulting in a trespass and the early watering-out of one of their oil wells. ${ }^{185}$ The court stated that it was presented with the issue of "whether a trespass is committed when secondary recovery waters from an authorized secondary recovery project cross lease lines." ${ }^{186}$ After discussing the utility of EOR operations the court stated: "We conclude that if, in the valid exercise of its authority to prevent waste, protect correlative rights, or in the exercise of other powers within its jurisdiction, the Commission authorizes secondary recovery projects, a trespass does not occur when the injected, secondary recovery forces move across lease lines, and the operations are not subject to an injunction on that basis. The technical rules of trespass have no place in the consideration of the validity of the orders of the Commission." 187 To apply the general rules of surface invasions would interfere with the public policy considerations behind secondary recovery operations which, the court found, should be encouraged as a matter of "public necessity." "I88 In reaching its decision, the court referenced Professors Howard Williams and Charles Meyers:

182. R.R. Comm'n of Tex. v. Manziel, 361 S.W.2d 560 (Tex. 1962).

183. Id. at 561 .

184. Id.

185. Id. at 561-65.

186. Id. at 567.

187. Id. at $568-69$.

188. Id. at 568 . 


\begin{abstract}
What may be called a "negative rule of capture" appears to be developing. Just as under the rule of capture a landowner may capture such oil or gas as will migrate from adjoining premises to a well bottomed on his own land, so also may he inject into a formation substances which may migrate through the structure to the lands of others, even if it thus results in the displacement under such land of more valuable substances. ... ${ }^{189}$
\end{abstract}

The Manziel case might be more assuring if it had been brought against the unit operator rather than having been an action to set aside a Railroad Commission order. While the consideration of trespass may have "no place" in a proceeding to determine the validity of a Commission order, trespass would be apposite in a private tort action. The Manziel court appeared to acknowledge this distinction:

[W]e are not confronted with the tort aspects of such practices. Neither is the question raised as to whether the Commission's authorization of such operations throws a protective cloak around the injecting operator who might otherwise be subjected to the risks of liability for actual damages to the adjoining property. . . ${ }^{190}$

Even so, the Manziel court did discuss trespass in detail, and was sympathetic to the view that traditional rules of trespass may not be appropriate for subsurface invasions that are the result of an activity carried-out in the public interest. The court seems to suggest that a regulatory approval, issued in the public interest, is required if traditional trespass rules are to be avoided.

The Alabama Supreme Court reached a similar decision in Phillips Petroleum Co. v. Stryker, ${ }^{191}$ where enhanced-recovery through injection of dry gas within a unitized oil and gas field allegedly drained the plaintiff's oil reserves. ${ }^{192}$ In reversing a jury award of nearly $\$ 26.9$ million to the plaintiff based on claims of trespass, negligence, fraud, and nuisance, the court found that to hold the defendant liable would be against the state's policy to promote secondary recovery to prevent oil and gas waste. ${ }^{193}$ Instead of suing for damages, the court explained that the plaintiff should have engaged in his own recovery operations, or sought to participate in the unit. ${ }^{194}$

The Louisiana Supreme Court has also allowed the public interest in field unitization to trump the absolute protection of subsurface property rights. In (1995))

189. Id. at 568 (quoting Howard Williams \& Charles Meyers, Oil and Gas LaW, $§ 204.5$

190. Id. at 566

191. Phillips v. Petroleum Co. v. Stryker, 723 So. 2d 585 (Ala. 1998).

192. Id. at 586.

193. Id. at $586,591$.

194. Id. 
Nunez v. Wainoco Oil \& Gas Co., ${ }^{195}$ the court rejected a landowner's trespass claim against a well operator, where the operator drilled a well that allegedly bottomed out on the plaintiff's property two miles below the surface. ${ }^{196}$ Notably, the plaintiff's property was within a unitized area created by the Commissioner of Conservation, but the plaintiff declined to lease his land to the defendant, who was authorized to create and operate the unit. ${ }^{197}$ In rejecting the plaintiff's trespass claim, the Nunez court recognized that Louisiana law historically allowed claims of subsurface trespass where a well bottoms out on the land of another without his or her consent. ${ }^{198}$ Here, though, the court found that the state's creation of the Conservation Commission, along with the state's policy to ensure that "an irreplaceable natural resource should not be subjected to avoidable waste," 199 created "a qualification of sorts in one's rights in private property." 200 In light of these statutory developments, and the current regulatory structure favoring unitization as the method to reconcile the correlative rights of resource owners in a common pool, the court found there was no legally actionable trespass in the case. ${ }^{201}$

In Crawford v. Hrabe ${ }^{202}$ the Kansas Supreme Court found that a lessee (Crawford) was not prohibited from injecting off-site wastewater into the lessor's (Hrabe) subsurface for the secondary recovery of oil, nor was he liable for trespass. ${ }^{203}$ The court surveyed other jurisdictions' treatment of subsurface trespass of wastewater, discovering that the orthodox rules of trespass applied to surface trespass do not usually apply to the subsurface, and that when water is injected to increase production on the lessor's land, no actionable trespass occurs. ${ }^{204}$ The Kansas Supreme Court reasoned that injecting wastewater for enhanced-recovery operations was a practical and efficient use of a potentially hazardous waste product. ${ }^{205}$

195. Nunez v. Wainoco Oil \& Gas Co., 488 So. 2d 955 (La. 1986).

196. Id. at $956-58$.

197. $I d$. at 956 .

198. Id. at $958-59$.

199. Id. at 960 .

200. Id. at 962 .

201. Id. at 964 .

202. Crawford v. Hrabe, 44 P.3d 442 (Kan. 2002).

203. Id. at 452 (citing Holt v. Sw. Antioch Sand Unit, Fifth Enlarged, 292 P.2d 998 (Okla. 1955)).

204. Id. at 448-50; R.R. Comm'n of Tex. v. Manziel, 361 S.W.2d 560 (Tex. 1962); Geo-Viking, Inc. v. Tex-Lee Operating Co., 817 S.W.2d 357 (Tex. App. 1991), rev'd per curiam, No. D-1678, 1992 WL 80263 (Tex. Apr. 22, 1992), vacated, 839 S.W.2d 797 (Tex. 1992).

205. Crawford, 44 P.3d at 453 . 
In Syverson v. North Dakota Industrial Commission, ${ }^{206}$ the court upheld the North Dakota Industrial Commission's order authorizing a unitized enhanced-recovery operation over the objection of a small number of lessors, where the record indicated that they were given a fair opportunity to join the unit but refused to do so. ${ }^{207}$ The court noted that the unit operations were ultimately designed to increase recovery from the reservoir and that the lessors were not entitled to complain in the absence of any evidence showing actual damages. ${ }^{208}$ The lessors presented no evidence whatsoever to support their opposition to the formation of the unit. ${ }^{209}$

In Tidewater Oil Co. v. Jackson, ${ }^{210}$ the United State Court of Appeals for the Tenth Circuit held that the injection of wastewater for enhanced-recovery constitutes an actionable trespass when the injected water flooded the neighboring plaintiff's oil wells, even though the operator held a regulatory permit authorizing the operations. ${ }^{211}$ The court explained:

[T] hough a water flood project in Kansas be carried on under color of public law, as a legalized nuisance or trespass, the water flooder may not conduct operations in a manner to cause substantial injury to the property of a non-assenting lessee-producer in the common reservoir, without incurring the risk of liability therefor. ${ }^{212}$

To establish liability, "[i]t is sufficient that the water flooding activities were intentional and the consequences foreseeable. They were actionable, even though lawfully carried on, if they caused substantial injury to the claimants. ${ }^{213}$ But because the activity was lawful under a conservation agency order, the Tenth Circuit reversed an award for punitive damages.

Similarly, in Hartman v. Texaco Inc. ${ }^{214}$ the New Mexico Court of appeals concluded that an oil and gas operator who suffered actual damages from a water-flooding operation conducted on neighboring lands had a cause of action for trespass. ${ }^{215}$ However, the court rejected the plaintiff's claim for statutory

206. Syverson v. N.D. State Indus. Comm'n, 111 N.W.2d 128 (N.D. 1961).

207. Id. at $131,134$.

208. Id. at 131

209. Id. at 134 .

210. 320 F.2d 157 (10th Cir. 1963).

211. Id. at 162 .

212. Id. at 163.

213. Id. at 164.

214. 937 P.2d 979 (N.M. Ct. App. 1997).

215. Id. at 980 . 
recovery of double (punitive) damages, concluding that the statute did not apply in the case of a subsurface trespass. ${ }^{216}$

Oklahoma recognizes a cause of action for private nuisance when injected water actually injures a neighbor, even though the injection is authorized by the Corporation Commission for secondary hydrocarbon recovery. ${ }^{217}$ This supports the idea that if there is actual interference with commercial use of the subsurface, then some recovery under tort law may be warranted even if the defendant's operations are authorized by a regulatory commission or agency. This is consistent with case law in other states, where plaintiffs have been able to recover for actual damages resulting from enhanced-recovery operations. ${ }^{218}$

In a decision by the United States Court of Appeals for the Eighth Circuit, the court found that a claim of trespass will succeed when a mineral owner seeks to recover for damages in the circumstance where the mineral owner's tract lies within the unit area of injection wells used for enhanced-recovery operations. ${ }^{219}$ This holding was embraced by the Arkansas Supreme Court in Jameson v. Ethyl Corp. ${ }^{220}$ The court required the unit operator to account and pay damages for production drained from the plaintiff's (a fee mineral owner's) property that was attributable to the enhanced-recovery operations, though the court did permit water-flooding operations to continue on public policy grounds. ${ }^{221}$ The court explained:

[W]e are unwilling to extend the rule of capture further. By adopting an interpretation that the rule of capture should not be extended insofar as operations relate to lands lying within the peripheral area affected, we, however, are holding that reasonable and necessary secondary recovery processes of pools of transient minerals should be permitted when such operations are carried out in good faith for the purpose of maximizing recovery from a common pool. The permitting of this good faith recovery process is conditioned, however, by imposing an obligation on the extracting party to compensate the owner of the depleted lands for the minerals extracted in excess of natural depletion, if any, at the time of taking and for any special damages which may have been caused to the depleted property. ${ }^{222}$

216. Id. (construing N.M. STAT. § 30-14-1.1 (1978)).

217. See Greyhound Leasing \& Fin. Corp. v. Joiner City Unit, 444 F.2d 439 (10th Cir. 1971); Gulf Oil Corp. v. Hughes, 371 P.2d 81 (Okla. 1962); Boyce v. Dundee Healdton Sand Unit, 560 P.2d 234 (Okla. Civ. App. 1975).

218. See Greyhound Leasing, 444 F.2d at 440 (granting recovery based on private nuisance for damage caused by salt-water encroachment associated with secondary recovery operations); Boyce, 560 P.2d at 237 (granting recovery for nuisance claim for damages caused by water flooding).

219. Young v. Ethyl Corp., 521 F.2d 771, 774 (8th Cir. 1975).

220. 609 S.W.2d 346 (Ark. 1980).

221. Id. at 351 .

222. $I d$. 
In Baumgartner v. Gulf Oil Corp.,${ }^{223}$ the Nebraska Supreme Court found that no trespass results from water-flooding when the plaintiff (the holder of an oil and gas lease) rejected a fair and reasonable offer to participate in a unitization plan approved by the Nebraska Oil and Gas Conservation Commission. ${ }^{224}$ The court did, however, indicate that the plaintiff may be entitled to recover any profits he could prove would have been realized through continued primary recovery operations uninhibited by the neighboring enhanced-recovery operations, in which he declined to participate. ${ }^{25}$

In contrast to water-flooding operations for enhanced-recovery of hydrocarbons, trespass issues posed by hydraulic fracturing, or fracking, did not until recently receive favorable treatment by the courts. The process of fracking stimulates "tight" formations containing oil or natural gas by pumping fluid (typically water) and proppants (sand, ceramic beads, or bauxite that follow the fluid and prop open the cracks in the rock) down the production well at high pressure to create cracks in the rock, which are held open by the proppants after the injected fluid is removed to increase the permeability of the formation, thus allowing the oil and gas contained therein to flow. Fracking is thus considered a well-completion technique, necessary for primary recovery, and has not involved voluntary or compulsory unitization.

In Gregg v. Delhi-Taylor Corp., the Texas Supreme Court held that courts, not the Railroad Commission, have primary jurisdiction to determine whether a fracturing operation may result in a trespass and whether relief is appropriate. ${ }^{226}$ By analogizing cracks that result from fracking operations and cross property lines to drill bits that cross property lines, the Gregg court characterized the cracks as a direct and intentional invasion and could thus constitute a subsurface trespass. ${ }^{227}$

In Geo-Viking, Inc. v. Tex-Lee Operating Co.,${ }^{228}$ the Texas Supreme Court initially followed its ruling in Gregg. In the Geo-Viking case, the operator of an oil well, Tex-Lee, sued a well-service company, Geo-Viking, for improperly fracking a well. ${ }^{229}$ On appeal, Geo-Viking argued that the trial court should have instructed the jury, in calculating damages, to disregard the amount of oil production that would have been obtained from fractures

223. 168 N.W.2d 510 (Neb. 1969).

224. Id. at 516 .

225. Id. at 519 .

226. 344 S.W.2d 411, 415-16 (Tex. 1961).

227. Id. at $416-17$.

228. 839 S.W.2d 797 (Tex. 1992).

229. Geo-Viking, Inc. v. Tex-Lee Operating Co., 817 S.W.2d 357, 359 (Tex. App. 1991), rev'd per curiam, No. D-1678, 1992 WL 80263 (Tex. Apr. 22, 1992), vacated, 839 S.W.2d 797 (Tex. 1992). 
extending beyond the boundaries of the production unit leased by Tex-Lee. ${ }^{230}$ The Texas Court of Appeals for the Sixth District rejected Geo-Viking's argument, citing the rule of capture, which "permits the owner of a tract to drill as many wells on his land as the Railroad Commission will allow and provides that he is not liable to adjacent landowners whose lands are drained as a result of his operations."231 The Texas Supreme Court originally reversed the appellate court's decision, finding that the rule of capture is precluded in the context of hydraulic fracturing, because a trespass occurs when adjacent lands are invaded by the frack operation. ${ }^{232}$ However, the Texas Supreme Court eventually withdrew its opinion and its writ of error at the request of the parties, declaring that the "application [of the writ of error] was improvidently granted," 233 concluding that "we should not be understood as approving or disapproving the opinions of the court of appeals analyzing the rule of capture or trespass as they apply to hydraulic fracturing." ${ }^{234}$ Unfortunately, the Texas Supreme Court's decision created more confusion than clarity as to whether hydraulic fracturing across property boundaries amounts to a trespass.

In 2005, in the case of Mission Resources, Inc. v. Garza Energy Trust, ${ }^{235}$ the Texas Court of Appeals for the Thirteenth District held that Texas recognizes a cause of action for trespass resulting from hydraulic fracturing operations that cross property lines, ${ }^{236}$ relying on the Texas Supreme Court's holding in Gregg. ${ }^{237}$ The Texas Supreme Court reversed, holding that hydraulic fracturing was not an actionable trespass where the only harm shown was the drainage of hydrocarbons as result of fracking, reasoning that the resulting drainage of hydrocarbons was protected by the rule of capture. ${ }^{238}$ The court specifically addressed the question of whether a defendant well operator engaged in fracking would be liable for trespass if injected proppants and fluids migrated to the plaintiff's land two miles below the surface and drained the oil and gas on the plaintiff's property. ${ }^{239}$ The court reasoned that trespass

230. Id. at 363-64.

231. Id. at 364 (citing Brown v. Humble Oil \& Ref. Co., 83 S.W.2d 935, 940 (Tex. 1935)).

232. Geo-Viking, Inc. v. Tex-Lee Operating Co., No. D-1678, 1992 WL 80263 (Tex. Apr. 22, 1992), vacated, 839 S.W.2d 797 (Tex. 1992).

233. Geo-Viking, 839 S.W.2d at 798.

234. $I d$.

235. 166 S.W.3d 301 (Tex. App. 2005), overruled by Coastal Oil \& Gas Corp. v. Garza Energy Trust, 268 S.W.3d 1 (Tex. 2008).

236. Id. at 310 .

237. $I d$. at 311 .

238. Coastal Oil \& Gas Corp. v. Garza Energy Trust, 268 S.W.3d 1 (Tex. 2008).

239. Id. at 9 . 
requires actual injury, and that trespass injury should not be inferred when the physical invasion occurs far below the surface. ${ }^{240}$ The court also explained that it should not usurp the lawful authority of the Texas Railroad Commission to decide to regulate or not regulate fracturing; should not allow the litigation process to determine the extent of harm (drainage) that is caused by fracturing; and should not allow an actionable trespass (by changing the rule of capture) when the oil and gas industry does not "want or need the change."241 Moreover, the court reasoned that allowing litigation over recovery of drained hydrocarbons resulting from fracking would force judges and juries to make difficult factual determinations based on proof "hidden below miles of rock," and render decisions without taking into account "social policies, industry operations, and the greater good," which are important in determining to what extent fracking should subject to tort liability. ${ }^{242}$ The court ultimately held that subsurface draining of oil and gas through fracking was not actionable in tort but that non-draining damage to wells or to the oil and gas formation might be. ${ }^{243}$ In a concurring opinion, Justice Willett indicated he would have gone further and held that, not only was fracturing not an actionable trespass, it was not a trespass at all. ${ }^{244}$ His concurring opinion discussed the necessity of hydraulic fracturing to the recovery of hydrocarbons.

In Garza, the Texas Supreme Court emphasized the public policy interest in facilitating hydrocarbon recovery by fracking. Likewise, in the EOR cases - adjudicated not only in Texas but in many other states as well-the courts have placed great emphasis on the states' statutory policies encouraging enhanced-recovery operations to promote the public's interest in efficient hydrocarbon production. In the latter cases, the courts have also focused on the existence of a state regulatory body to balance the needs of various rights holders and refused tort recovery for those who declined to participate in unitization. Both Garza and the EOR cases, however, signal willingness by the courts to allow plaintiff recovery where there is actual damage to, or interference with the use of, a plaintiff's tangible property. Simply stated, the courts have refused any absolute protection of property rights in the deep subsurface, but have preserved limited protection that would allow property owners to recover monetary compensation for damage to property caused by actual and substantial harm or interference. Allowing recovery for actual 
damage to property is different from finding that a landowner possesses the type of property right in the subsurface that empowers the owner to prevent others from injecting fluids into the pore space underlying the owner's property; it is this type of absolute ownership doctrine the courts seem to have clearly rejected in the context of EOR and hydraulic fracturing. This judicial approach to managing the use of pore space supports the notion that GCS project developers could be authorized to access and use pore space without being required to seek permission from landowners, or compensate landowners for the right, to permanently sequester $\mathrm{CO}_{2}$ in the deep subsurface.

\subsection{Underground Fluid Waste Disposal Model}

An activity perhaps more closely analogous to $\mathrm{CO}_{2}$ sequestration than natural gas storage or EOR is underground fluid-waste injection. Unlike the natural gas storage case law, the underground waste-injection cases show that courts have consistently rejected any notion that property owners have the absolute right to prevent the underground migration of fluid waste into their pore space, or are entitled to compensation for such use of their pore space, when the waste injection is conducted pursuant to regulatory approval. And unlike EOR, fluid-waste-disposal operations do not involve the unitization of the underground reservoir - neither costs nor profits of the disposal operation are shared by affected landowners.

In each fluid-waste case, the courts have placed great weight on the public interest and regulatory approval associated with the underground injection of fluid wastes, modifying common law relating to subsurface property rights accordingly. At the same time, though, each of the courts held open the possibility that a plaintiff could recover damages if it could show that the migration of injected waste caused actual harm to, or interference with the use of, her property. While there is no physical difference between the subsurface pore space used for underground waste injection and natural gas storage-in fact both activities may be carried out in the same geologic formations (where the geology may also be suitable for geologic sequestration of $\mathrm{CO}_{2}$ ) - the judicial protection afforded to subsurface property rights in the context of waste injection is quite different than for natural gas storage. In much of the nation, it appears that most underground waste-injection operations conducted pursuant to federal or state authorization under the UIC program that do not cause actual harm to adjacent properties may be carried out without compensation being paid to the surrounding landowners, because the activity is considered necessary and in the public interest. For example, municipalities 
in Florida appear to be injecting roughly 3 billion tons a year of treated wastewater without the consent of subsurface owners. ${ }^{245}$

Attempts by landowners to prevent or exclude subsurface waste disposal have not been successful in the absence of establishing actual and substantial harm to the use and enjoyment of their property. For example, in Raymond $v$. Union Texas Petroleum Corporation, ${ }^{246}$ the plaintiffs claimed salt water injected under adjacent lands had migrated to their subsurface property. ${ }^{247}$ Because the state regulatory agency issued a permit for the saltwater injection, the federal district court in Louisiana concluded that migration of the salt water into neighboring pore space "is not unlawful and does not constitute a legally actionable trespass." ${ }^{248}$ However, in dictum, the court did instruct that a permit does not preclude recovery for actual damages and for inconvenience. ${ }^{249}$

In Mongrue v. Monsanto Co., the United States Court of Appeals for the Fifth Circuit concluded that migrating wastewater did not cause the injecting party to be liable for a taking without just compensation. ${ }^{250}$ In so doing, the Fifth Circuit affirmed the United States District Court for the Eastern District of Louisiana decision that the appellants (Mongrue) did not establish a claim of unconstitutional taking because Monsanto was not a "private entity authorized by law to expropriate" for a "public and necessary purpose," as required by the Louisiana Constitution. ${ }^{251}$ Despite this ruling, the Fifth Circuit indicated they could seek remedies on other grounds. ${ }^{252}$ To elucidate its holding, the Fifth Circuit cited the district court's conclusion that "upon a proper showing of damages, appellants may recover under a state unlawful trespass claim against Monsanto regardless of the permit allowing for injection." 253 Unfortunately for the appellants, although they asserted at the district court level that the injector had committed subsurface trespass, the Fifth Circuit did not rule on the issue because the appellants agreed to the dismissal (with prejudice) of their trespass claim against Monsanto. ${ }^{254}$ In the

245. Three billion tons/year is about the same as the mass of $\mathrm{CO}_{2}$ produced/year by between 750 and 1000 medium-sized $(500 \mathrm{Mw})$ coal-fired power plants. See Keith et al., supra note 33, at 501A.

246. Raymond v. Union Tex. Petroleum Corp., 697 F. Supp. 270 (E.D. La. 1988).

247. Id. at 271.

248. $I d$. at 274 .

249. Id. The court concluded there was no legally actionable trespass in this case, but that a permit does not preclude a landowner from recovering compensation for damage to property or measurable inconvenience (citing Nunez v. Wainoco Oil \& Gas Co., 488 So. 2d 955, 964 (La. 1986)).

250. Mongrue v. Monsanto, 249 F.3d 422, 432 (5th Cir. 2001).

251. Id. at $429-32$.

252. Id. at 432 n. 17 .

253. $I d$.

254. $I d$. 
same year the Mongrue case was decided, the Fifth Circuit affirmed Raymond in Boudreaux v. Jefferson Island Storage \& Hub, L.L.C., reasoning that migration of injected wastewater is not "unlawful" if a valid regulatory permit authorizes the action. ${ }^{255}$

In an Oklahoma case, West Edmond Salt Water Disposal Ass'n v. Rosecrans, the defendant injected salt water into a stratum already containing salt water. ${ }^{256}$ The Oklahoma Supreme Court found that a neighboring landowner had no cause of action for trespass because the owner had suffered no actual damages. The court explained that no oil or gas was under the plaintiff's property and "if the formation into which such valueless substance [salt water] is injected is already filled with a similar or identical valueless substance, a portion of which is displaced by the water migrating from the lands of the defendants into and under the lands of the plaintiffs, we are unable to see where any injustice has been done to plaintiffs, or the value of their property or their rights in their property in any wise diminished." ${ }^{257}$ The court additionally concluded that underground disposal is the most practical solution for dealing with wastewater and reasoned "[i]f such disposal of salt water is forbidden unless oil producers first obtain the consent of all persons under whose lands it may migrate or percolate, underground disposal would be practically prohibited." 258 Even so, the Oklahoma Supreme Court recognized a cause of action when actual damages resulting from saltwater injection were proved. In West Edmond Hunton Lime Unit v. Lillard, salt water injected into a formation migrated onto adjacent land and interfered with the plaintiff's oil and gas operations. ${ }^{259}$ In affirming an award for the plaintiff, the court characterized the action as a trespass. ${ }^{260}$

Another example of how interference with oil and gas production resulting from wastewater disposal led a court to conclude an actionable trespass had occurred is found in Cassinos v. Union Oil Co. ${ }^{261}$ Union Oil, the oil and gas lessee on adjacent lands, secured permission from the surface owner to inject wastewater, and obtained the necessary injection well permit from the State of California. ${ }^{262}$ The injected wastewater was targeted for a saline aquifer not believed to contain any hydrocarbons. Such did not turn out

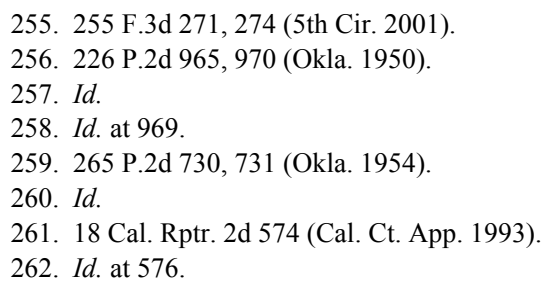


to be the case. The mineral owner, Cassinos, initiated suit claiming that Union Oil trespassed on its mineral rights by injecting wastewater into hydrocarbonproducing strata and interfered with that production. ${ }^{263}$ The court was presented with evidence that the wastewater "communicated" with and affected oil wells and other oil and mineral producing areas. ${ }^{264}$ Thus, the court held this to be a trespass against the mineral estate and issued an injunction against any further wastewater injection along with a damage award of $\$ 5$ million. ${ }^{265}$ The Cassinos court distinguished this situation from one in which injected wastewater invades strata that are devoid or depleted of mineral resources. Citing Sunray Oil Co. v. Cortez Oil Co. ${ }^{266}$ the Cassinos court suggested that the mineral owner would have no actionable damage claim under the aforementioned circumstances. In Sunray, the court found "there is no probability that any possible oil producing formation exists in the land in question which would be materially affected to plaintiff's detriment by the use of the well in question for the disposal of salt water by defendant."267 Consequently, the Sunray court declined to find an actionable trespass against the mineral estate. ${ }^{268}$

In an unreported Texas case, FPL Farming Ltd. v. Texas Natural Resource Conservation Commission, ${ }^{269}$ the Texas Court of Appeals for the Third District adjudicated plaintiff's claim that the Texas Natural Resource Conservation Commission's grant of two permits for injection of waste 2,300 to 2,500 meters $(7,400$ to 8,200 feet) below the surface into a saltwater formation under the plaintiff's property constituted a taking of private property without just compensation. The court noted the legal trend that "property owners do not have the right to exclude deep subsurface migration of fluids" and rejected the argument that "migration alone will impair [their] existing rights." "[B] ecause of [the agency's] . . . expertise in the geological effects of subsurface migration of injectates," the court deferred to the agency's finding

263. Id.

264. Id. at 580 .

265. Id. at 586.

266. 112 P.2d 792 (Okla. 1941).

267. Id. at 795. The court also cited W. Edmond Salt Water Disposal Ass'n v. Rosecrans, 226 P.2d 965 (Okla. 1950).

268. But see Starrh \& Starrh Cotton Growers v. Aera Energy LLC, 63 Cal. Rptr. 3d 165, (Cal. Ct. App. 2007) (describing how wastewater from oil well percolated from a surface pit and migrated to neighboring land, causing degradation of water, which if returned to its natural state had some potential value for irrigating certain salt-tolerant crops).

269. PL Farming, Ltd. v. Tex. Natural Res. Conservation Com'n, No. 03-02-00477-CV, 2003 WL 247183 (Tex. App. Feb. 6, 2003). 
that no existing rights would be impaired by the injection. ${ }^{270}$ The court did, however, indicate that landowners could seek damages from the injector if the waste migrated and caused some measure of harm. Although the plaintiff testified that the two permits issued by the Conservation Commission (which were the heart of the controversy) precluded the plaintiff from acquiring its own permit to store salt water or inject waste into the pore space beneath its property, the court found there was no evidence that the existing permits would impede the plaintiff's ability to use the pore space for such purposes in the future. ${ }^{271}$

As for the takings claim itself, the FPL court rejected the argument that the act of issuing the permits on the part of the Conservation Commission amounted to a per se taking under Loretto I. ${ }^{272}$ The court found that Loretto I did not apply because the plaintiff could not show that migration of the waste would prevent it from engaging in brine mining or waste injection operations. ${ }^{273}$ In other words, the plaintiff failed to establish it lost the right or the ability to use the property. The court concluded that plaintiff could seek damages from the well operator for any actual harm caused by the migration of injected waste into the plaintiff's pore space because the mere possession of a permit did not shield operator from civil liability. ${ }^{274}$

Three years after the court of appeals decision, FPL filed a separate suit to enjoin the injector's operations and alleged claims for trespass, unjust enrichment, and negligence. ${ }^{275}$ The trial court rejected each of FPL's contentions. ${ }^{276}$ On appeal, the court considered whether FPL had a trespass claim where the agency had approved the injector's amended permit while fully knowing that the injected wastewater was expected to migrate into the deep subsurface beneath FPL's property. ${ }^{277}$ The court found the Texas Supreme Court's prior decisions in Garza and Manziel controlling. ${ }^{278}$ Specifically, the court reasoned that, like the agency-approved subsurface migration of injected salt water in Manziel, which "did not cause a trespass when the water migrated across property lines," the state agency's

270. $I d$. at $* 4$.

271. $I d$.

272. 458 U.S. 419.

273. Id. at $* 5$.

274. $I d$.

275. FPL Farming Ltd. v. Envtl. Processing Sys., 305 S.W.3d 739 (Tex. App. 2009).

276. Id. at 740 .

277. Id. at 741 .

278. Id. at 742-45. Garza is discussed supra at text accompanying notes 235-40. Manziel is discussed supra at text accompanying notes 179-87. 
authorization of the defendant's amended permit presented the court with an analogous case. ${ }^{279}$ While noting that "the rules of trespass were 'technical' and should not affect the validity of the Railroad Commission's orders," the court nonetheless recognized that Manziel "relied heavily on the fact that the [Railroad] Commission had approved the operation." 280 The court then considered the policy and purposes of the Injection Well Act, given that "the Commission in this case also was required to consider various interests." 281 The court ultimately held that "under the common law, when a state agency has authorized deep subsurface injections, no trespass occurs when fluids that were injected at deep levels are then alleged to have later migrated at those deep levels into the deep subsurface of nearby tracts. ${ }^{" 282}$ As such, the court determined that "no actionable common-law trespass [had] occurred." 283

The landmark decision on subsurface waste disposal is Chance v. BP Chemicals, Inc. ${ }^{284} \mathrm{BP}$ Chemicals secured a Class I underground injection well permit to dispose of hazardous chemical waste. ${ }^{285}$ Subsequently, neighboring landowners initiated a class-action suit wherein they asserted that the injected waste trespassed into their subsurface pore space. ${ }^{286}$ In Chance, the plaintiffs sought an injunction against further wastes disposal along with $\$ 1$ billion in damages. ${ }^{287}$ To support their claim, the plaintiffs cited a 1993 decision of the Ohio Supreme Court, Columbia Gas Transmission Corp. v. An Exclusive Natural Gas Storage Easement, which involved the determination of compensation due for the appropriation of an underground gas storage easement. ${ }^{288}$ The Ohio Supreme Court found this earlier decision in the natural gas storage context to be inapplicable to the situation in Chance, which involved the injection and disposal of hazardous waste over 800 meters $(2,600$ feet) underground into a saline aquifer. ${ }^{289}$ The court explained:

We find that the situation before us is not analogous to those present in the oil and gas cases, around which a special body of law has arisen based on special circumstances not present here. [These cases are] fundamentally dissimilar to the

279. 305 S.W.3d at 743.

280. Id. at 744 (citations omitted).

281. $I d$.

282. Id at $744-45$.

283. Id. at 745 .

284. 670 N.E.2d 985 (Ohio 1996).

285. Id.

286. Id. at 986 .

287. $I d$.

288. Id. at 991 (citing Columbia Gas, 620 N.E.2d 48).

289. Id. at 989-91. 
unique situation before us, which involves the injection of waste byproducts from the production of industrial chemicals. ${ }^{290}$

The Chance court ultimately concluded that a landowner's subsurface right to exclude others extends only to invasions that "actually interfere with the [landowner's] reasonable and foreseeable use of the subsurface." ${ }^{291}$ The court expressly found that the trial court did not err in refusing to allow the plaintiff to present evidence that "environmental stigma associated with the deep wells had a negative effect on appellants' property values due to the public perception there may have been injectate under appellants' property and that the injectate may be dangerous. ${ }^{292}$ The Ohio Supreme Court placed significant weight on the fact that the plaintiffs had no specific evidence that defendant's wells were causing any problems, only opinion testimony that problems may arise in the future. ${ }^{293}$ In other words, a landowner may not recover damages for mere loss of speculative value. Since the injection of hazardous waste by BP Chemicals was not interfering with any reasonable and foreseeable use of plaintiff's property, the court held that migration of the waste into neighboring pore space was not compensable.

Relying on Willoughby Hills $v$. Corrigan, ${ }^{294}$ the Chance court found that "ownership rights in today's world are not as clear-cut as they were before the advent of airplanes and injection wells." 295 Although landowners may assert that ownership of land extends from heavens to the depths of the earth, their subsurface rights are limited. The court reasoned:

Just as a property owner must accept some limitations on the ownership rights extending above the surface of the property, we find that there are also limitations on property owners' subsurface rights. We therefore extend the reasoning of Willoughby Hills, that absolute ownership of air rights is a doctrine which 'has no place in the modern world,' to apply as well to ownership of subsurface rights. ${ }^{296}$

Although BP Chemicals was operating pursuant to valid state and federal permits, the Chance court did state that this in itself did not shield the

290. Id. at 991 .

291. Id. at 992

292. Id. at 993.

293. $I d$.

294. 278 N.E.2d 658, 664 (Ohio 1972) ("[T]he doctrine of the common law, that the ownership of land extends to the periphery of the universe ... has no place in the modern world.") (citing United States v. Causby, 328 U.S. 256 (1946)).

295. Chance, 670 N.E.2d at 992.

296. $I d$. 
company from liability. The class claims were ultimately deemed too speculative, but the court did indicate that one class member might have a valid claim because the migration of the subsurface waste may have forced that member to abandon plans to drill for natural gas. ${ }^{297}$ Thus, a mineral owner may have a valid trespass claim when the injected waste migrates across property lines and unreasonably interferes with access to recoverable minerals.

While the Chance court's logic for drawing a distinction between the gasstorage and waste-injection contexts is scant, the practical effect of the decision is sound. For instance, no structural or geophysical difference exists between the pore spaces at issue in Columbia Gas Transmission and Chance. ${ }^{298}$ In fact, gas storage has occurred in the same sandstone formation, the Mt. Simon, as was used for the particular hazardous waste wells at issue in Chance. Thus, while one could reasonably argue that geologic strata are of little use to most surface owners, an expectation on the part of a landowner to be compensated for subsurface natural gas storage of a valuable commodity was "reasonable and foreseeable" in Columbia Gas Transmission. On the other hand, in Chance, notice to potential members of the class affected by BP Chemical's hazardous waste injection operation had to be sent to more than 20,000 landowners. ${ }^{299}$ Those property owners not wishing to be involved sent in requests to opt out of the class. ${ }^{300}$ Considering the enormous number of plaintiffs involved in this case, if the court concluded that all class members were entitled to compensation for the mere migration of hazardous waste into their pore space, the entire practice of underground fluid waste injection would most likely have been curtailed in Ohio. Such an outcome would be detrimental because of the public-safety benefits derived from having fluid wastes disposed of hundreds to thousands of meters underground instead of in surface tanks or pools.

Today, use of the Mt. Simon stratum has been proposed for GCS as well. Since sequestered $\mathrm{CO}_{2}$ could migrate laterally over a very sizeable area (e.g., 100 s to 1,000 s of square-miles), ${ }^{301}$ requiring project developers to obtain consent from all pore-space owners within the migratory path of the $\mathrm{CO}_{2}$ plume, this could have the practical effect of prohibiting the development of

297. Id. at 994.

298. See Columbia Gas Transmission Corp. v. An Exclusive Gas Easement, 620 N.E.2d 48 (Ohio 1993); Chance, 670 N.E.2d 985.

299. Chance, 670 N.E.2d at 988.

300. Id.

301. See Pruess et al., supra note 1; Brennan \& Burruss, supra note 1, at 182; Gresham et al., supra note 1 , at 2900 . 
many sequestration projects due to the potentially crippling cost of such an obligation. If Chance is followed, then GCS project developers would not need to acquire pore-space rights prior to commencing operations, only an injection permit. However, should injected $\mathrm{CO}_{2}$ cause actual damages to neighboring properties or impair "reasonable or foreseeable" uses of pore space owned by neighboring property owners, the sequestration project operator would be liable for trespass damages, although the project itself would not be enjoined under Chance.

\subsection{Groundwater Aquifer Storage and Recharge Model}

A handful of states have mature permitting regimes to facilitate the storage of fresh water underground so that it may be withdrawn during dry periods. Aquifer storage and recovery, as this method of water storage is commonly known, is a promising solution for the future of freshwater management. ${ }^{302}$ However, in spite of relatively well-developed permitting programs in several states, courts have rarely discussed the issue of subsurface property rights in the context of underground storage of fresh water. ${ }^{303}$ California and Colorado are the exception. Both states have dealt with the issue directly, and both concluded that aquifer storage space is a public resource. ${ }^{304}$

The Constitution of the State of California confers broad powers on the state to safeguard its water supply and to apply it to maximum beneficial use. Article X, section 2 provides in part:

\footnotetext{
... because of the conditions prevailing in this State the general welfare requires that the water resources of the State be put to beneficial use to the fullest extent of which they are capable, and that the waste or unreasonable use or unreasonable method of use of water be prevented, and that the conservation of such waters is to be exercised with a view to the reasonable and beneficial use thereof in the interest of the people and for the public welfare. ${ }^{305}$
}

Although this constitutional provision continues by explicitly referring to surface waters, it has been judicially interpreted as applying to all natural

302. Kiel \& Thomas, supra note 39 .

303. Tara L. Taguchi, Comment, Whose Space Is It Anyway?: Protecting the Public Interest in Allocating Storage Space in California's Groundwater Basins, 32 Sw. U. L. Rev. 117, 119 (2003) (quoting SCOTt Slater, California Water LaW AND Policy 11-51 (1995)).

304. See Alameda Cnty. Water Dist. v. Niles Sand \& Gravel Co., 112 Cal. Rptr. 846, 851 (Cal. Ct. App. 1974); Bd. of Cnty. Comm'rs v. Park Cnty. Sportsmen's Ranch, LLP, 45 P.3d 693 (Colo. 2002).

305. CAL. CONST. art. X, $\S 2$. 
waters in the state, ${ }^{306}$ including waters artificially stored underground. ${ }^{307}$ With such a broad constitutional sanction allowing police-power regulation of California's water resources, it is not surprising that California courts established a public right to use subsurface pore space for storage. ${ }^{308}$ The leading case is City of Los Angeles v. City of Glendale. ${ }^{309}$

In Glendale, the California Supreme Court held that Los Angeles could inject water into an underground aquifer and retain its senior rights to that water as against other cities pumping water from aquifers. ${ }^{310}$ In analogizing the use of subsurface space to the use of a stream bed, the Glendale court relied on a California statute that codified a rule of law which had been developed during the mining days. ${ }^{311}$ The statute provides that any person may transport imported water in a natural stream bed and later reclaim it as long as his reclamation does not thereby diminish the water already lawfully appropriated by another. ${ }^{312}$ The court explained that the purpose of that rule was to avoid the construction of artificial waterworks when natural water facilities would accomplish the same purpose, and applied the logic of that rule to underground storage facilities, stating that "[i]t would be as harsh to compel plaintiff to build reservoirs when natural ones were available as to compel the construction of an artificial ditch beside a stream bed." 313

The ruling in Glendale was reaffirmed by the California Supreme Court in City of Los Angeles v. City of San Fernando. ${ }^{314}$ The court extended Glendale by holding, in effect, that under another section of the California Water Code,${ }^{315}$ mutual prescription ${ }^{316}$ of public water rights was barred. ${ }^{317}$ The effect

306. Joslin v. Marin Mun. Water Dist., 429 P.2d 889 (Cal. 1967).

307. See Alameda Cnty., 112 Cal. Rptr. 846.

308. See generally James H. Krieger \& Harvey O. Banks, Ground Water Basin Management, 50 CALIF. L. Rev. 56 (1962)

309. City of Los Angeles v. City of Glendale, 142 P.2d 289 (Cal. 1943).

310. Id. at 294.

311. $I d$.

312. CAL. WATER CODE $\S 7075$ (West 2011).

313. Glendale, 142 P.2d at 294.

314. 537 P.2d 1250, 1297 (Cal. 1975) (holding that the City of Los Angeles "is entitled to use the San Fernando basin for temporary storage of its water by means of artificial recharge and subsequent recapture.").

315. CAL. Civ. CODE $\S 1007$ (West 2007).

316. Mutual prescription is a groundwater doctrine stating that in the event of an overdraft of a ground-water basin, the available ground water will be apportioned among all the users in amounts proportional to their individual pumping rates. The doctrine was first proclaimed in City of Pasadena v. City of Alhambra, 207 P.2d 17 (Cal. 1949). The Pasadena court held that the commencement of an overdraft created a situation of adverse use against existing pumpers sufficient to establish rights in all users after the statutory period had run, necessitating pro rata reductions in the amounts which all pumpers were permitted 
of San Fernando was to prevent any private rights from attaching to public waters by prescription. ${ }^{318}$ As a consequence of San Fernando, a public body in California can import waters and use such waters to recharge groundwater basins without concern that third parties might, by capturing and using some of the artificially stored waters, establish prescriptive rights to the continued use of a portion of those waters. This judicial protection of a public entity's investment in underground storage and transmission was a significant factor in reducing the cost of such projects.

Neither Glendale nor San Fernando expressly discussed ownership of aquifer pore space, rather the ability to use pore space for ASR without compensating the owner was assumed. At least one commentator believes that San Fernando's "reaffirmation of [Glendale] manifests a clear judicial recognition of the right to store imported waters underground so long as that storage does not impair native groundwater rights." ${ }^{319}$ Moreover, neither case directly considered trespass as a barrier to aquifer storage and recovery. Instead, these cases focused on a water user's right to store surface waters underground and subsequently recapture that water without interference from other groundwater appropriators. That is, real property rights in pore space may only be implied by the holdings in San Fernando and Glendale. However, " $[t]$ he California Supreme Court's sanctioning of such storage without any recognition of a proprietary right on behalf of overlying owners suggests that overlying owners cannot object to groundwater storage beneath their property absent a showing of harm to a recognized right associated with their property ownership. ..." 320

Perhaps the most significant California decision for ASR is Alameda County Water District v. Niles Sand \& Gravel Co ${ }^{321}$ While San Fernando established a public right to transport and store imported waters underground, Niles extended underground public storage rights to limit overlying private property rights. Niles expressly recognized that the protection of underground storage capacity and a basin's water supply may require that otherwise legitimate activities overlying landowners be regulated. ${ }^{322}$ Niles involved the activity of a private company engaged in sand and gravel mining. ${ }^{323}$ As part of

to extract. $I d$. at 48 .

317. San Fernando, 537 P.2d at 1297-1313.

318. Id. at 1307.

319. Victor E. Gleason, Water Projects Go Underground, 5 ECOLOGY L.Q. 625, 640 (1976).

320. Kiel \& Thomas, supra note 39, at 28.

321. Alameda Cnty. Water Dist. v. Niles Sand \& Gravel Co., 112 Cal. Rptr. 846 (Cal. Ct. App. 1974).

322. Id. at 855 .

323. Id. at 846 . 
its operation, it pumped large quantities of ground water out of its pits and into a flood-control channel that flowed into the San Francisco Bay. ${ }^{324}$ After Niles engaged in its mining activity for ten years, the Alameda County Water District began recharging the groundwater basin with imported water. In seven years, the recharge raised the water table in the basin to the point at which the flow of ground water into the pit seriously threatened the mining operation.

Eventually, Niles instituted an inverse condemnation suit against the Water District claiming damages to his mining operation allegedly caused by the seepage of recharged ground water into the gravel pit. ${ }^{325}$ The Water District countered by asking the court to enjoin Niles from pumping ground water out of its pit and to award damages for ground water previously pumped from the pit. ${ }^{326}$ The trial court ruled in favor of the Water District, ${ }^{327}$ and the court of appeal affirmed ${ }^{328}$ The trial court concluded that Nile's pore space was subject to a "public servitude for water and water conservation purposes." 329 The court of appeal explained that because the ASR program was a legitimate exercise of the Water District's police power, the adverse effect on Nile's property was not compensable. ${ }^{330}$ Furthermore, the Niles court denied damages to the gravel pit for inverse condemnation and held instead that Niles was making an unreasonable use of underground storage space. ${ }^{331}$ By linking property rights in underground storage space to groundwater rights, the Niles court relied on the broad police power to protect water resources given to the state by the California constitution. ${ }^{332}$ By relying on the fact that water has been generally singled out for special treatment, ${ }^{333}$ California has been able to treat underground storage rights in a significantly different manner than it might have if it had been faced with the question of underground storage rights for other minerals.

324. Id. at 847 .

325. $I d$.

326. Id. at $847-48$.

327. Id. at 848 .

328. Id. at 846 .

329. Id. at 851 (quoting the trial court).

330. Id. at 855 .

331. Id. at 853 .

332. R. Clark, Western Ground Water Law, in 5 WATERS AND WATER RIGHTS §§ 18.1-18.2 (R. Clark ed., 1972).

333. Comprehensive statutes provide extensive regulation of all waters in California. The general state policy, to regulate all waters in a manner that will maximize their beneficial use, is found in CAL. WATER CODE $\S \S 100-108$ (West 2011). 
Interestingly, California codified the common-law rule that surface owners have the rights in anything permanently situated beneath the surface. ${ }^{334}$ In developing the doctrine of correlative rights, however, California courts have refused to apply the doctrine of absolute ownership ${ }^{335}$ to ground water since ground water is not permanently situated beneath the surface. This enabled the Niles court to find a servitude in the form of an underground storage right to predicated on the correlative rights exception carved out of the common-law rules. ${ }^{336}$ This public servitude was held to restrain overlying landowners from discharging more than their reasonable share of ground water found in the basin. ${ }^{337}$

In Colorado, the State's Supreme Court ruled that storing water in aquifer pores does not constitute a trespass. In Board of County Commissioners $v$. Park County Sportsmen's Ranch, LLP, ${ }^{338}$ the plaintiffs tried, by analogy to mineral law, ${ }^{339}$ to assert their ownership of the pore space under their property. Like the Ohio Supreme Court in Chance, the Colorado Supreme Court in Park County relied on the reasoning of the U.S. Supreme Court in Causby, holding that "[j]ust as a property owner must accept some limitations on the ownership rights extending above the surface of the property, we find that there are also limitations on property owners' subsurface rights." 340 The court rejected the application of mineral law, holding that mineral law is a special body of law distinct from water law. ${ }^{341}$ The court also noted that "[w]ater is a public resource, and any rights to it are usufructuary." ${ }^{342}$

The ASR cases highlight that courts often treat the protection of property rights somewhat like a moving target, one which is contingent upon and balanced against the promotion of important and well-defined public interests. If California's ASR approach to subsurface property rights is applied to GCS, then federal or state legislatures would declare that the permanent sequestration of $\mathrm{CO}_{2}$ in geologic formations furthers an important public

334. See CAL. Civ. CODE $\S 829$ (West 2011) ("Rights OF OWNER. The owner of land in fee has the right to the surface and to everything permanently situated beneath or above it.").

335. Katz v. Walkinshaw, 74 P. 766, 772 (Cal. 1903).

336. Alameda Cnty., 112 Cal. Rptr. at 853.

337. Id.

338. Board of County Comm'rs v. Park County Sportsmen's Ranch, LLP, 45 P.3d 693 (Colo. 2002).

339. Those two cases, Walpole v. State Board of Land Comm'rs, 163 P. 848, 849-50 (Colo. 1917), and Wolfley v. Lebanon Mining Co., 4 Colo. 112, 114 (1878), stand for the proposition that property ownership extended "to the center of the earth."

340. Board of County Comm'rs, 45 P.3d at 701.

341. Id. at 709 (holding that mineral cases "are clearly distinguishable from water cases").

342. Id. at 710 . 
interest - reducing greenhouse gas emissions to the atmosphere-and impose, through a valid exercise of police power, a public servitude over deep geologic formations suitable for permanent sequestration of $\mathrm{CO}_{2}$. If an ASR framework is applied, then a GCS project developer may not need to compensate property owners to use pore space for $\mathrm{CO}_{2}$ sequestration. This is especially likely if no harm to or interference with the use of subsurface property is caused by the migration of injected $\mathrm{CO}_{2}$; it might also be true even if damage is caused should the California standard be followed.

One problem with this analysis is that courts may not believe that ASR and GCS are analogous. Water resources in the western part of the United States have long been treated as a special public resource. In the West, water is in short supply but is essential to life and economic growth. Water law, both statutory and case law, reflects the special nature of freshwater resources. Both state legislatures and courts may be unwilling to think of GCS as analogous to water resources. Hence, the likelihood that GCS may be legally treated similarly to ASR is perhaps remote.

\subsection{Summary}

The case law arising from industrial and commercial fluid-injection operations is instructive of how subsurface property rights might be effectively dealt with in the context of GCS projects. This body of case law shows that courts have consistently held certain underground fluid injection activities - i.e., enhanced hydrocarbon recovery, underground waste disposal, and freshwater storage and recharge - to be in the public interest and thus protected from claims of subsurface trespass (1) when the activity is licensed under a state or federal regulatory program, and (2) where the property owner is unable to prove actual harm to, or interference with use and enjoyment of, the land resulting from the injection operations.

Thus, while courts have rejected any absolute protection of rights in the subsurface on behalf of landowners, they have preserved limited landowner rights to use and exploit the subsurface and to recover money damages for actual and substantial harm caused by subsurface invasions. Similarly, courts will entertain landowner suits in trespass and nuisance when airborne particles and pollution invade the landowner's airspace and cause actual and substantial harm. ${ }^{343}$ In airspace pollution cases, courts consider whether the invasion

343. See, e.g., Davis v. Georgia-Pacific Corp., 445 P.2d 481, 483 (Or. 1968) (holding that intrusion of fumes, gases, and microscopic particles on the property of another can constitute a trespass in addition 
actually interfered with the plaintiff's use and enjoyment of property or caused actual harm. ${ }^{344}$ In subsurface invasion cases, courts consider essentially these same factors and generally reach similar conclusions. In both lines of cases, courts apply a "liability rule" 345 — which permits an airspace or subsurface intrusion without permission of property owners so long as the violator pays damages for any harm caused. This is in contrast to a "property rule"-which would allow such an intrusion only with prior permission of the property owner. ${ }^{346}$

Ultimately, the extent to which GCS projects are developed in areas where the subsurface is already being used commercially for natural gas storage, hydrocarbon production, or other uses will depend upon the cost of obtaining the rights to use the subsurface pore space. In these scenarios, the value of compensation will be derived not solely from the value resulting from sequestration, but from the value of existing or future, investment-backed uses of the subsurface that would be precluded by GCS. In other cases though, where the geologic formation is appropriate for $\mathrm{CO}_{2}$ sequestration but not for other commercial uses, the costs associated with acquiring pore-space rights might be nominal or perhaps even zero because no other economic use is precluded or impaired and might even be essentially limited to compensation for surface activities necessary to GCS operations. ${ }^{347}$ As a result, there may well be a sliding scale of compensation for subsurface pore space based not on the existence of a property right, but on the value of that right based on the existing or reasonably foreseeable uses of the pore space.

to nuisance); JAMES A. Henderson, JR. ET AL., THE TORT'S PROCESS 402-03 (7th ed. 2007) (discussing how some courts have allowed claims for trespass, in addition to nuisance, for claims based on the intrusion of smoke, gases, or odors).

344. HENDERSON ET AL., supra note 343, at 400-01.

345. See Guido Calabresi \& A. Douglas Melamed, Property Rules, Liability Rules, and Inalienability: One View from the Cathedral, 85 HARV. L. REV. 1089, 1092 (1975) (reasoning that some entitlements are protected by a "liability rule" (i.e., damages) which permits violation of the entitlement without permission of the owner so long as the violator pays damages).

346. Id. at 1092 (reasoning that some entitlements are protected by a "property rule" (i.e., an injunction) which permits violation of the entitlement only with permission of the property owner).

347. See Brown v. Legal Found. of Wash., 538 U.S. 216, 240 (2003) (holding that the state's taking of private property did not violate the Fifth Amendment because the value of the property, measured by the owner's pecuniary loss, was zero). 


\section{Potential Legal and Commercial Frameworks for Permitting Access and Use of Pore Space for GeOlogic $\mathrm{CO}_{2}$ Sequestration}

At present, there is limited state-level authority and practically no federallevel authority for handling the subsurface property rights issues associated with the use of pore space for $\mathrm{CO}_{2}$ sequestration as well as other commercial and industrial subsurface injection of fluids. Although state law determines underlying property rights to both state-owned and privately-owned land, federal law will need to address the acquisition of GCS rights regarding federal land. While the Environmental Protection Agency has the authority under the Underground Injection Control program to permit and regulate geologic sequestration of $\mathrm{CO}_{2}$, the Agency currently has no authority to consider the subsurface property issues attendant to permanent geologic $\mathrm{CO}_{2}$ sequestration. A legal framework for GCS is needed that balances the interests of private property owners with the public benefit of sequestration, and reduces the possibility of interference with other commercial uses of the subsurface that are also in the public interest. To be workable, such a framework must allow regulators to consider the trade-offs between private interests and the public benefit of a proposed GCS project and determine the most equitable and beneficial use of the pore space. A successful framework would increase the potential for either avoiding most subsurface property disputes outright or resolving them at the outset in a stable and predictable environment. The remainder of this article evaluates a range of common-law, statutory, and regulatory approaches to managing the access and use of pore space for geologic sequestration of $\mathrm{CO}_{2}$ and concludes by proffering a framework for addressing this issue in a manner that is fair and equitable to both GCS project operators and private property owners.

\subsection{Federally-Coordinated Statutory and Regulatory-Based Framework Is Optimal}

The decision tree in Figure 1 begins with the question of whether anyone enjoys a recognized property right in subsurface pore space for geologic $\mathrm{CO}_{2}$ sequestration. The answer to that question triggers a series of additional policy and legal questions. How these questions are resolved will determine whether and how geologic $\mathrm{CO}_{2}$ sequestration will be able to move forward. Consider first the lower branch of Figure 1, which assumes that no vested property rights are currently recognized in subsurface pore space for GCS. In this case, both Congress and the states have the option of defining property rights in the pore space in some manner. In the absence of such action, sooner or later the 
issue will be resolved in the courts on a case-by-case basis. Judicial reconciliation could result in a patchwork of different rights from state to state. On the other hand, legislative action to fix the existence and nature of property rights would have the benefit of establishing clear and uniform principles that would yield predictable outcomes, particularly if Congress passed legislation that is applicable throughout the country. Additionally, such efforts at standardization could help to foster coordination when geologic basins underlie several different states.

Alternatively, the states could enact uniform legislation-perhaps drafted under the auspices of the National Conference of Commissioners on Uniform State Laws. Uniform state laws would avoid the issue of whether a federal law would be constitutional under the Supremacy and Commerce Clauses. Historically, issues of title and basic incidents of privately-owned and stateowned real property have been the province of state law, while the federal government has largely passed regulatory laws. Federal law would need to be narrowly tailored to have any chance of both passage and judicial review. For example, such a law might declare a public easement in deep pore space for the purposes of $\mathrm{CO}_{2}$ sequestration. 


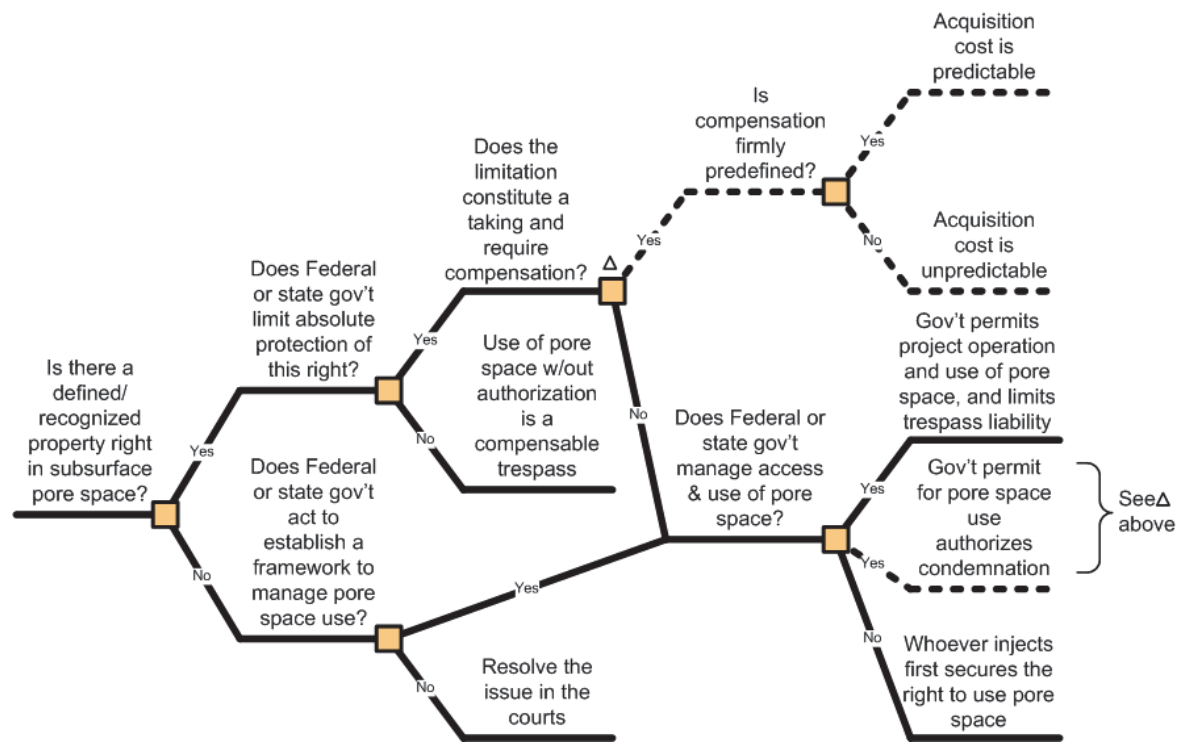

Figure 1: Alternative approaches to managing access and use of pore space for GCS. The dashed lines represent approaches utilizing government condemnation of private property. ${ }^{348}$

The upper branch of the decision tree in Figure 1 is the more optimal path-especially if the law is found to have already determined the basic nature and extent of property rights to deep subsurface pore space. Both federal and state governments have intervened to regulate land use and could do the same for the deep subsurface uses. Should lawmakers choose to regulate, the question becomes whether the intervention meets the constitutional standard for a taking of private property within the meaning of the Fifth Amendment to the U.S. Constitution. ${ }^{349}$ Assuming no taking, this approach would have the simplifying effect of leaving government with the same discretionary choices outlined above for establishing a framework for use of the deep subsurface. On the other hand, should the U.S. Supreme Court decide (or let stand a lower court rulings to the same effect) that use or regulation of pore space for GCS constitutes a Fifth Amendment taking, then

348. Figure adapted from CCSReg Project, Interim Report, Carbon Capture and Sequestration: Framing the Issues for Regulation 63-68 (2009), http://www.ccsreg.org/pdf/CCSReg_3_9.pdf.

349. U.S. CONST. amend. V. 
the government must decide (and courts must ultimately pass on the legality of) whether and how to fix the constitutionally required just compensation for such a taking. If courts determined that the degree of taking associated with using pore space at depths of a kilometer or more imposes a negligible burden on the use rights of surface owners, then the courts could set compensation at a nominal level - perhaps even zero. A decision not to regulate would not, in itself, preclude sequestration projects, but developers of such projects would then be burdened with the tasks of identifying owners and negotiating contracts to secure long-term robust sequestration rights without regulatory guidance and certainty. In the rural parts of the West, where much of the land is federal and private holdings are often large, this might not be terribly difficult. In the East, where small, fractional ownership of real property predominates, acquiring rights for secure sequestration could entail transactions with thousands of individual landowners.

Note that several of the routes through the decision tree (Figure 2) result in outcomes that could make it economically difficult to develop large, commercially viable GCS projects. If the federal or state governments do not intervene to manage or limit the protection of private property rights for the use of pore space for geologic $\mathrm{CO}_{2}$ sequestration, then the cost of acquiring pore-space rights could adversely affect GCS project economics and greatly increase the cost of generating electricity. ${ }^{350}$ For instance, if the use of relatively thin sandstones with low mass-to-volume storage capacities for GCS result in $\mathrm{CO}_{2}$ plumes that migrate over hundreds to thousands of squarekilometers, then the cost of acquiring the right to use pore space, should compensation be required, could make the project uneconomical (see Table 2). ${ }^{351}$ Such costs might compare with a sequestration project's operational capital cost that, conservatively, will also be very high. ${ }^{352}$

Research suggests that the cost of acquiring the right to use pore space for GCS may not be trivial and could increase the overall cost of generating electricity with $\mathrm{CO}_{2}$ capture by a fraction of a percent to up to 40 percent, and account for up to 20 percent of the total levelized cost of electricity when all GCS-related costs are factored into generation facilities' revenue requirements

350. Gresham et al., supra note 1, at 2900-01; R. Lee Gresham, Geologic $\mathrm{CO}_{2}$ Sequestration and Subsurface Property Rights: A Legal and Economic Analysis 143-71 (2010) (Ph.D. thesis, Department of Engineering \& Public Policy, Carnegie Mellon University).

351. Gresham, supra note 350, at 143-71.

352. Sean T. McCoy \& Edward S. Rubin, Variability and Uncertainty in the Cost of Saline Formation Storage, 1 ENERGY PROCEDIA 4151, 4151-58 (2009). 
(see Table 2). ${ }^{353}$ This could render electric generation facilities' capture of $\mathrm{CO}_{2}$ for permanent geologic sequestration in saline aquifers unprofitable. ${ }^{354}$ Thin formations with low porosities will likely lead to high injection costs, large $\mathrm{CO}_{2}$ plumes, and high costs for acquiring necessary property rights - all of which will increase the levelized cost of operating a power plant with $\mathrm{CO}_{2}$ capture and, in turn, customer electricity prices. For example, the combined annualized cost of sequestration (i.e., injection field characterization and injection facility/field capital and operational costs) and property rights acquisition alone could increase the levelized cost of electricity for an integrated gasification combined cycle (IGCC) electric generation facility with $\mathrm{CO}_{2}$ capture by as much as nearly $\$ 30$ per MWh (see Table 2 ). ${ }^{355}$

\begin{tabular}{|c|c|c|c|c|c|}
\hline & $\begin{array}{c}\text { Frio } \\
\text { Sandstone } \\
\text { (TX) }\end{array}$ & $\begin{array}{l}\text { Mt. Simon } \\
\text { Sandstone } \\
\text { (IL) }\end{array}$ & $\begin{array}{l}\text { Oriskany } \\
\text { Sandstone } \\
\text { (PA) }\end{array}$ & $\begin{array}{l}\text { Medina } \\
\text { Sandstone } \\
\text { (PA) }\end{array}$ & Source \\
\hline $\begin{array}{l}\text { Facility Net Electric } \\
\text { Output (MW) }\end{array}$ & 530 & 530 & 530 & 530 & $\begin{array}{c}\text { CMU } \\
\text { CEES } \\
(2010) \& \\
\text { Gresham } \\
(2010)^{357}\end{array}$ \\
\hline $\begin{array}{l}\text { Operational time } \\
\text { horizon (years) }\end{array}$ & 30 & 30 & 30 & 30 & \\
\hline $\begin{array}{l}\mathrm{CO}_{2} \text { sequestered (metric } \\
\text { tons } \mathrm{CO}_{2} / \mathrm{yr} \text { ) }\end{array}$ & $3.9 \times 10^{6}$ & $3.9 \times 10^{6}$ & $3.9 \times 10^{6}$ & $3.9 \times 10^{6}$ & $\begin{array}{c}\text { CMU } \\
\text { CEES } \\
(2010) \& \\
\text { Gresham } \\
(2010)^{358}\end{array}$ \\
\hline $\begin{array}{l}\mathrm{CO}_{2} \text { emitted (metric } \\
\text { tons } \mathrm{CO}_{2} / \mathrm{yr} \text { ) }\end{array}$ & $1.8 \times 10^{5}$ & $1.8 \times 10^{5}$ & $1.8 \times 10^{5}$ & $1.8 \times 10^{5}$ & $\begin{array}{c}\text { CMU } \\
\text { CEES } \\
(2010) \& \\
\text { Gresham } \\
(2010)^{359}\end{array}$ \\
\hline
\end{tabular}

353. Gresham, supra note 350, at 159-63.

354. Id. at $163-65$.

355. Id. at $159-63$.

356. See generally id. at 143-71; see also Gresham et al., supra note 1, at 2900-01.

357. CARnegie Mellon Univ. CTR. For ENERGy AND EnVtl. Studies (CMU CEES), INTEGRATEd Environmental Control Model Carbon Sequestration Addition Version 6.2.4, Pittsburgh, Pa: CARNEGIE MELLON University (May 7, 2010); Gresham, supra note 339, at 159.

358. Gresham, supra note 350 , at 159.

359. Id. 


\begin{tabular}{|c|c|c|c|c|c|}
\hline & $\begin{array}{c}\text { Frio } \\
\text { Sandstone } \\
(\mathrm{TX})\end{array}$ & $\begin{array}{l}\text { Mt. Simon } \\
\text { Sandstone } \\
\text { (IL) }\end{array}$ & $\begin{array}{c}\text { Oriskany } \\
\text { Sandstone } \\
\text { (PA) }\end{array}$ & $\begin{array}{l}\text { Medina } \\
\text { Sandstone } \\
\quad(\text { PA) }\end{array}$ & Source \\
\hline $\begin{array}{l}\text { Levelized cost of } \\
\text { generation }(\$ / y r)^{1}\end{array}$ & $306 \times 10^{6}$ & $306 \times 10^{6}$ & $306 \times 10^{6}$ & $306 \times 10^{6}$ & $\begin{array}{l}\text { Gresham } \\
(2010)^{360}\end{array}$ \\
\hline $\begin{array}{l}\text { Levelized cost of } \\
\text { electricity (\$/MWh) }\end{array}$ & 88 & 88 & 88 & 88 & $\begin{array}{c}\text { Gresham } \\
(2010)\end{array}$ \\
\hline $\begin{array}{l}\text { Wholesale electricity } \\
\text { price }(\phi / \mathrm{kWh})^{2}\end{array}$ & 7.1 & 6.3 & 5.7 & 5.7 & $\begin{array}{c}\text { EIA } \\
(2008) \& \\
\text { Gresham } \\
(2010)^{361}\end{array}$ \\
\hline $\mathrm{CO}_{2}$ emission cost $(\$ / \mathrm{yr})$ & $2.6 \times 10^{6}$ & $2.6 \times 10^{6}$ & $2.6 \times 10^{6}$ & 2. $6 \times 10^{6}$ & $\begin{array}{l}\text { Gresham } \\
(2010)^{362}\end{array}$ \\
\hline $\begin{array}{l}\mathrm{CO}_{2} \text { pipeline levelized } \\
\text { cost }(\$ / y r)^{3}\end{array}$ & $8.2 \times 10^{6}$ & $10 \times 10^{6}$ & $10 \times 10^{6}$ & $10 \times 10^{6}$ & $\begin{array}{l}\text { Gresham } \\
(2010)^{363}\end{array}$ \\
\hline $\begin{array}{l}\mathrm{CO}_{2} \text { sequestration } \\
\text { levelized cost }(\$ / y r)^{4}\end{array}$ & $8.7 \times 10^{6}$ & $7.4 \times 10^{6}$ & $91 \times 10^{6}$ & $44 \times 10^{6}$ & $\begin{array}{l}\text { Gresham } \\
(2010)^{364}\end{array}$ \\
\hline $\begin{array}{l}\text { Pore-space lease term } \\
\text { (years) }\end{array}$ & 100 & 100 & 100 & 100 & \\
\hline $\begin{array}{l}\text { Areal extent of } \mathrm{CO}_{2} \\
\text { plume }(\mathrm{km} 2)\end{array}$ & 440 & 330 & 4900 & 2400 & $\begin{array}{l}\text { Gresham } \\
(2010)^{365}\end{array}$ \\
\hline $\begin{array}{l}\text { Annual pore-space lease } \\
\text { cost }(\$ / y r)^{5}\end{array}$ & $\begin{array}{c}590,000- \\
11 \times 10^{6}\end{array}$ & $\begin{array}{l}440,000- \\
8 \times 10^{6}\end{array}$ & $\begin{array}{l}6.7 \times 10^{6}- \\
120 \times 10^{6}\end{array}$ & $\begin{array}{l}3.2 \times 10^{6}- \\
60 \times 10^{6}\end{array}$ & $\begin{array}{l}\text { Gresham } \\
(2010)^{366}\end{array}$ \\
\hline $\begin{array}{l}\text { Generation facility } \\
\text { revenue requirement } \\
(\$ / \mathrm{MWh})\end{array}$ & $96-99$ & $95-98$ & $107-123$ & $121-152$ & $\begin{array}{l}\text { Gresham } \\
(2010)^{367}\end{array}$ \\
\hline
\end{tabular}

${ }^{1}$ Includes cost of capture.

${ }^{2}$ Equals the wholesale price of electricity reported by the Energy Information Agency for the North American Reliability Corporation region corresponding to the geographic location where each of the sandstone formations are situated.

${ }^{3}$ Based on $100 \mathrm{~km}$ pipeline length.

${ }^{4}$ Includes annualized injection facility/field capital cost, annualized injection field characterization capital cost, and injection facility/field annual operating cost.

${ }^{5}$ Annual lease rate range \$5-100/acre year.

360. Id. at 160 .

361. Id.; ENERgy INFormation AgENCy, AVERAGE Wholesale Price by NERC REgion ELECTRIC UTILITIES AND POWER MARKETERS 2001-2007, http://www.eia.gov/cneaf/electricity/wholesale/ wholesalet2.xls (last visited July 21, 2010).

362. Gresham, supra note 350 , at 160.

363. Id.

364. $I d$.

365. $I d$.

366. $I d$.

367. $I d$. 


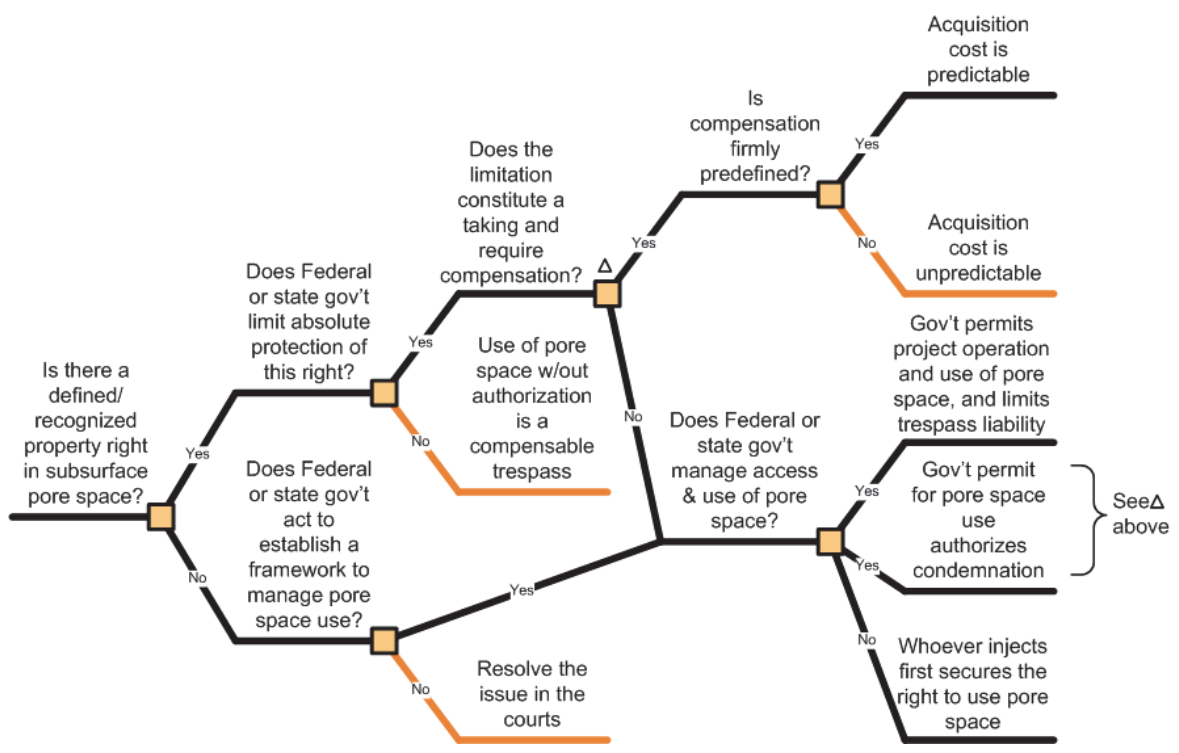

Figure 2: Approaches to managing access and use of pore space that could make development of GCS projects costly and difficult. ${ }^{368}$

If neither Congress nor the states act to establish a framework for managing access and use of deep pore space for geologic $\mathrm{CO}_{2}$ sequestration, resolution will be left to the courts to sort out under tort, property, and contract law. Relying on the courts to adjudicate disagreements about subsurface property rights and contractual obligations between GCS project developers/operators and private property owners could significantly delay, if not permanently halt, the development of many GCS projects. This discussion of judicial barriers to GCS development assumes, of course, that the appropriate property owners will be amenable to the use of the deep pore space in which they hold a vested property interest. Hold-out landowners could prevent development of GCS projects, especially in the eastern United States where there are innumerable small private land holdings. Absent eminent domain or unitization authority, hold-outs could effectively stymie implementation of GCS projects or make them very expensive, such as by bargaining for an ongoing time and volume-based storage fee. However, the cost of acquiring pore-space rights via condemnation or unitization could be economically prohibitive. Faced with highly variable and unpredictable 
acquisition costs, would-be GCS developers might be discouraged from moving forward with a project before even attempting negotiations with the appropriate surface owners and mineral owners. Assuming the urgent need to address climate change, this is clearly an outcome that must be avoided.

\subsection{Application of a Property Rule-Natural Gas Storage and Field Unitization}

If pore space is determined to be a protected by a property rule, then the owner's lack of prior actual use, or the lack of any reasonable, future nonspeculative, investment-backed uses ${ }^{369}$ for the pore space would not dissuade courts from concluding that all affected surface owners (and in some cases mineral owners) have the right to exclude others from using pore space for geologic $\mathrm{CO}_{2}$ sequestration and are entitled to compensation if the pore space is used. ${ }^{370}$ Figure 2 represents this expansive view of private property rights in the subsurface in the context of $\mathrm{CO}_{2}$ sequestration. Such would be the result if the natural gas storage model is followed. Under this approach, existing and non-speculative, investment-backed future uses of the pore space would be relevant only in determining the amount of just compensation due. ${ }^{371}$ This approach may be a natural extension of the Montana, North Dakota, and Wyoming legislation, which declare that surface owners hold title to subsurface pore space. ${ }^{372}$ Thus, this approach would most likely require compensation to surface owners for any $\mathrm{CO}_{2}$ sequestration, either by bilateral agreement or through the exercise of eminent domain.

Alternatively, compulsory-unitization legislation similar to that used to facilitate the enhanced recovery of oil and gas could be adapted for GCS. Unitization for GCS would essentially be a contractual instrument backed by statutory authority that would force non-consenting landowners to allow the use of their pore space for $\mathrm{CO}_{2}$ sequestration if a statutorily specified majority of the pore-space owners, on an acreage basis, have voluntarily agreed to the creation of a sequestration unit. Note that compulsory unitization, in the

369. For the purpose of this paper, "non-speculative, investment-backed use" and "non-speculative, investment-backed expectation" mean the ability to recover actual mineral resources or engage in current or imminent subsurface activities that have substantial economic value.

370. See Loretto I, 458 U.S. 419, 436-38 (1982); Tahoe-Sierra Pres. Council, Inc. v. Tahoe Reg'l Planning Agency, 535 U.S. 302, 322 (2002).

371. For a discussion of approaches to determine value and just compensation, see Wilson \& de Figueiredo, supra note 3, at 10122; Klass \& Wilson, supra note 3, at 417-23.

372. See Mont. Code AnN. § 82-11-180 (2009); N.D. CEnT. CodE § 47-31-01-08 (2006 \& Supp. III); Wyo. STAT. ANN. § 34-1-152 (2009). 
context of a GCS project, is not fundamentally different from eminent domain. The difference lies in the fact that a statutory percentage of owners, on an acreage basis, must first agree voluntarily to the establishment of a GCS project before non-consenting owners could be forced to transfer sequestration rights for just compensation through a regulatory proceeding that is, practically speaking, similar to court proceeding in eminent domain, although administered by a regulatory agency instead of by courts.

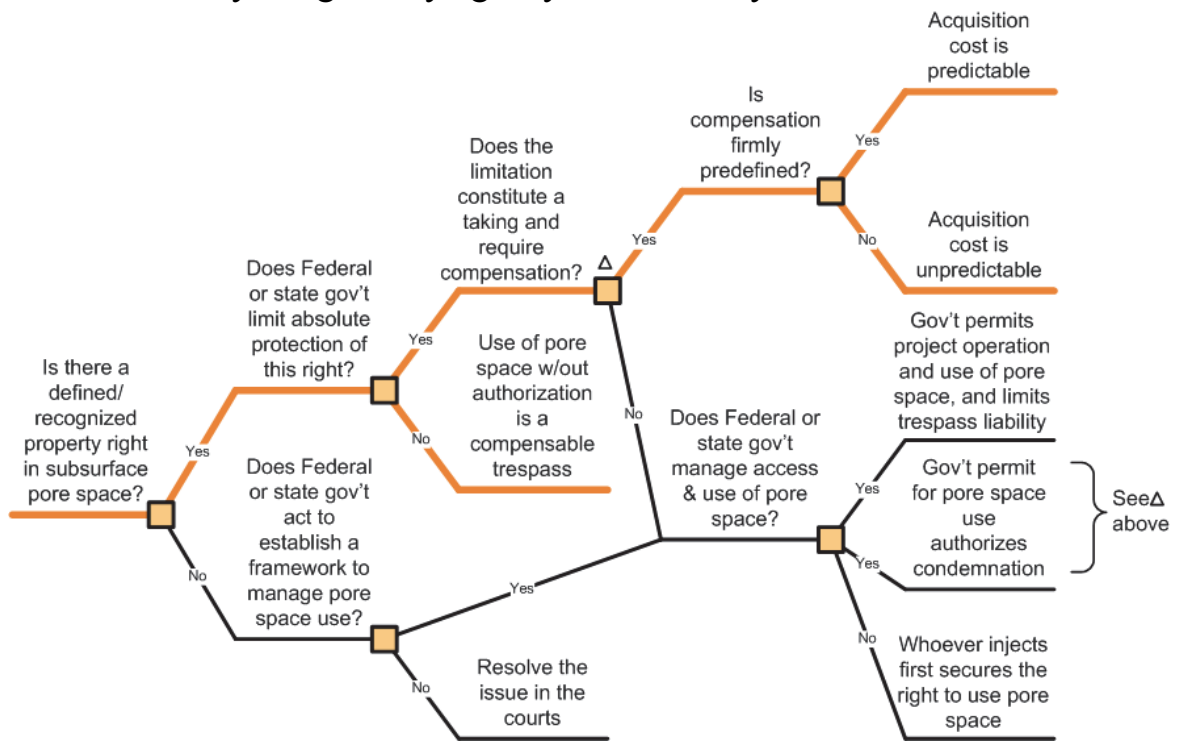

Figure 3: Property rule approach to managing access and use of pore space for geologic $\mathrm{CO}_{2}$ sequestration. ${ }^{373}$

As discussed in Section 2.1, the Interstate Oil and Gas Compact Commission issued a model statute for GCS that contemplates the acquisition of property rights in the same manner as for achieving compulsory unitization for EOR or, alternatively, through eminent domain as is done for natural gas storage projects: "The Model General Rules and Regulations propose the required acquisition of these storage rights and contemplate the use of state natural gas storage eminent domain powers or oil and gas unitization processes to gain control of the entire storage reservoir." ${ }^{374}$ The IOGCC Model Statute has the advantage of working through the well-established mechanisms of state

373. Figure adapted from CCSReg Project, supra note 348.

374. The Interstate OIL AND GAS COMPACT COMMission, supra note 9. 
oil and gas agencies that are familiar with drilling and reservoir regulations. The IOGCC Model Statute is not without its shortcomings, however. One limitation of the IOGCC's Model Statute is that it does not authorize $\mathrm{CO}_{2}$ sequestration to be conducted in formations containing economicallyrecoverable amounts oil and gas or other valuable resources. ${ }^{375}$ Under the IOGCC's model, a GCS developer could not acquire (either by unitization or eminent domain) the right to use a formation that had once produced minerals without first establishing, by agreement or otherwise, that the minerals are exhausted. Over the large areas that could be affected by a $\mathrm{CO}_{2}$ sequestration operation, this may be difficult to prove. Moreover, the question of just how depleted mineral-bearing strata must be before the pore space can be used for $\mathrm{CO}_{2}$ sequestration may be addressed differently from state to state, and some states view the issue of mineral exhaustion very favorably to the mineral estate owner, taking into account potential new production methods and technologies. ${ }^{376}$ This means that if a GCS project was developed and it was later discovered that $\mathrm{CO}_{2}$ was being injected into, or was migrating into, strata containing recoverable resources, then the only option may be to discontinue sequestration operations. Thus, project developers may well be motivated to identify formations, such as saline aquifers, that have never yielded valuable minerals and have little prospect of doing so.

Another important question to consider regarding the IOGCC Model Statute's unitization alternative is whether the proposition of having to acquire property rights in the subsurface from the required threshold of landowners - perhaps thousands of landowners - to develop a GCS site will make the unitization model administratively unwieldy and economically unattractive. The IOGCC unitization model requires a GCS project developer to identify and negotiate in good faith with all property owners "having property interests affected by the storage facility." ${ }^{377}$ Consequently, the unitization model would likely result in higher costs associated with acquiring the pore-space rights necessary for geologic $\mathrm{CO}_{2}$ sequestration than would be realized under the more simple eminent domain approach that limits required compensation to only those instances where the injection and migration of $\mathrm{CO}_{2}$ materially impairs current or non-speculative, investment-backed future uses of the subsurface. An expansive view of subsurface property rights modeled after unitization or, for that matter, under the natural-gas-storage eminent

375. Id. at $\S 3(\mathrm{a})(3)$.

376. See Int'l Salt v. Geostow, 697 F. Supp. 1258, 1270 (W.D.N.Y. 1988); accord Dept. of Transp. v. Goike, 560 N.W.2d 365 (Mich. Ct. App. 1996).

377. The InTERState OIL AND GAS COMPACt COMMission, supra note 9, at § 3(a)(2). 
domain model, that appears to entitle all affected landowners to compensation, regardless of any actual harm, could greatly discourage the development of GCS due to the potentially overwhelming cost of having to compensate all property owners overlying the $\mathrm{CO}_{2}$ sequestration reservoir. ${ }^{378}$ With $\mathrm{CO}_{2}$ sequestration, this could be true even if the value of just compensation is clearly defined and constrained, as in Loretto, ${ }^{379}$ because the $\mathrm{CO}_{2}$ plume could migrate over hundreds to thousands of square-kilometers. ${ }^{380}$ Of course, the nature and extent of the money expended and the infrastructure needed will depend on how widely GCS is deployed, where it is deployed, and how integral a techno-strategy GCS becomes in America's approach to limiting GHG emissions.

On balance, the IOGCC's eminent-domain model, properly constrained to situations where a regulatory permit is insufficient to safeguard GCS, is preferable to the unitization model. Unitization is necessary to facilitate the enhanced recovery of hydrocarbons that must be allocated to resource owners, and unitization has always been controversial. ${ }^{381}$ The controversy arises because not all operators and royalty owners have faith that the proposed unit operations will actually result in greater hydrocarbon recovery and profits. Moreover, all working-interest owners are responsible, at least as a matter of accounting, for their respective share of the costs of unit operations. Finally, because an entire oil and gas reservoir, or substantial portion thereof, is unitized and managed by a single unit operator, the production and costs must be allocated on a fair-share basis. Determining the appropriate allocation of costs and production is highly contentious and often defeats unitization efforts.

On the other hand, GCS is essentially a disposal operation, and the costs of such an operation are likely to be borne by the party or parties that secure the necessary permits. While there may be profits resulting from disposal fees, carbon credits, and other incentives, the business seems more analogous to waste-disposal operations than it is to unitization for enhanced hydrocarbon recovery. One important exception would be where GCS is done in tandem with enhanced hydrocarbon recovery. But again, the need for unitization in this circumstance arises from the production of hydrocarbons, not from the carbon-sequestration objective.

378. Gresham et al., supra note 1, at 2900-01; Gresham, supra note 339, at 143-71.

379. See Loretto II, 446 N.E.2d 428, 435 (1983) (fixing compensation for the taking at one dollar).

380. Gresham et al., supra note 1, at 2900; Gresham, supra note 339, at 160.

381. See generally, Owen L. Anderson, Mutiny: The Revolt Against Unsuccessful Unit Operations, 30 Rocky MTN. Min. L. INST. 13-1 (1985). 


\subsection{Federal Ownership of Pore Space}

Just as Causby ${ }^{382}$ confirmed that federal legislation cut off property interests in the higher airspace, in theory, legislation authorizing the use of the deep subsurface for $\mathrm{CO}_{2}$ sequestration could similarly truncate property interests in the deep subsurface, except in connection with those uses that are currently in existence or subject to non-speculative, investment-backed expectations. Numerous courts have held that a surface owner's interest in the subsurface is "limited" at best, relying on Causby and other cases limiting the surface owner's right to control the airspace. ${ }^{383}$ Arguably, even if states expressly provide by statute that a surface owner has a property right in the pore space, as Wyoming, North Dakota, and Montana have done, such a statecreated property interest may be limited by the judicial application of Causby to subsurface rights that places "objective" limits on rights to the subsurface. ${ }^{384}$ In other words, the argument would be that just as Wyoming could not vest in surface owners the right to the airspace far above their property as a result of the objective, background principles expressed in Causby, Wyoming cannot vest in surface owners the right to the deep subsurface as a result of courts' application of Causby to the subsurface. ${ }^{385}$

This argument is consistent with a 2008 article by John Sprankling in the UCLA Law Review entitled Owning the Center of the Earth ${ }^{386}$ In this article, Sprankling argues that private property rights to land should not extend more than 300 meters $(1,000$ feet) below the surface of the earth and that the subsurface beneath that threshold should belong to the federal government. ${ }^{387}$ The article did not focus on geologic $\mathrm{CO}_{2}$ sequestration specifically, but instead focused on the issue of subsurface ownership in connection with today's technological ability to develop various energy and climate change technologies, including GCS, that must make use of the subsurface in ways not contemplated in the past. ${ }^{388}$ Sprankling contends that, based on case law involving subsurface water, oil and gas development, and hazardous waste injection, among others, American law has never determined whether a landowner's rights extend more than two miles below the surface, and that

382. 328 U.S. 256 (1946).

383. See, e.g., Chance v. BP Chems., Inc., 670 N.E.2d 985, 992 (Ohio 1996); Coastal Oil \& Gas Corp. v. Garza Energy Trust, 268 S.W.3d 1, 11 (Tex. 2008).

384. Chance, N.E.2d at 992.

385. Id.

386. See Sprankling, supra note 73 , at 1022-25.

387. Id. at 982 .

388. Id. at 1029-32. 
even case law within two miles of the surface is largely inconsistent. ${ }^{389} \mathrm{He}$ concludes that property owners should have some rights below the surface to accommodate foundations, trees, and other normal surface facilities, but those rights should not extend more than 300 meters (1,000 feet) below the surface. ${ }^{390}$

Following Sprankling's argument, Congress or the states could enact legislation declaring a "public highway" of sorts in the subsurface at a specified depth below the surface of the earth just as has been done with navigable airspace. ${ }^{391}$ Such an easement would not need to transfer ownership of subsurface minerals to the federal government, and the easement could even be expressly subordinate to mineral rights, but require accommodation ${ }^{392}$ by mineral owners to minimize conflicts. The legislation could also establish a system for compensating property owners with existing uses of the subsurface below that depth if they are harmed by $\mathrm{CO}_{2}$ injection and truncate the establishment of future private property rights and expectations going forward. ${ }^{393}$ This regime would need to formalize and standardize procedures for authorizing access and use of pore space for $\mathrm{CO}_{2}$ sequestration. Such a framework would obviate many of the property rights conflicts that might arise when $\mathrm{CO}_{2}$ sequestration projects involve the use of pore space in more than one state. Figure 3 shows the path federal or state governments could take in establishing ownership and control of deep pore space for the purpose of $\mathrm{CO}_{2}$ sequestration.

While such an approach would almost certainly facilitate the development of $\mathrm{CO}_{2}$ sequestration by simplifying the process of accessing the right to use pore space for GCS and constraining the cost of acquiring subsurface property rights, it would almost certainly invite takings challenges. Oil and gas resources are being developed onshore at depths far greater 300 meters, and this development is occurring based upon an assumption of ownership rights in those resources to all depths. Moreover, given the weight of and factual variety of case law addressing subsurface uses, the need for such a public easement is questionable in terms of facilitating appropriate uses of pore spaces in the public interest. Congress has not found it necessary to declare an

389. Id. at 1020 .

390. Id. at $1026-28,1031$.

391. See 42 U.S.C. $\S 171$ (2006).

392. See, e.g., Getty Oil Co. v. Jones, 470 S.W.2d 618, 621-22 (Tex. 1971) and Sun Oil Co. v. Whitaker, 483 S.W.2d 808, 810-11 (Tex. 1972).

393. Sprankling does recognize the potential need to acknowledge and honor "all existing rights to extract specific valuable minerals, at least to the extent appropriate to ensure a reasonable return on prior investments." Sprankling, supra note 73, at 1037-38. 
airspace easement; yet, the courts have had no problem safeguarding the use of airspace by aircraft. Lastly, but most importantly, it is doubtful that it will ever be politically feasible for the Congress or state legislatures to implement such a legal framework, which would certainly depend on the political climate and attitudes of the courts over the coming decades.

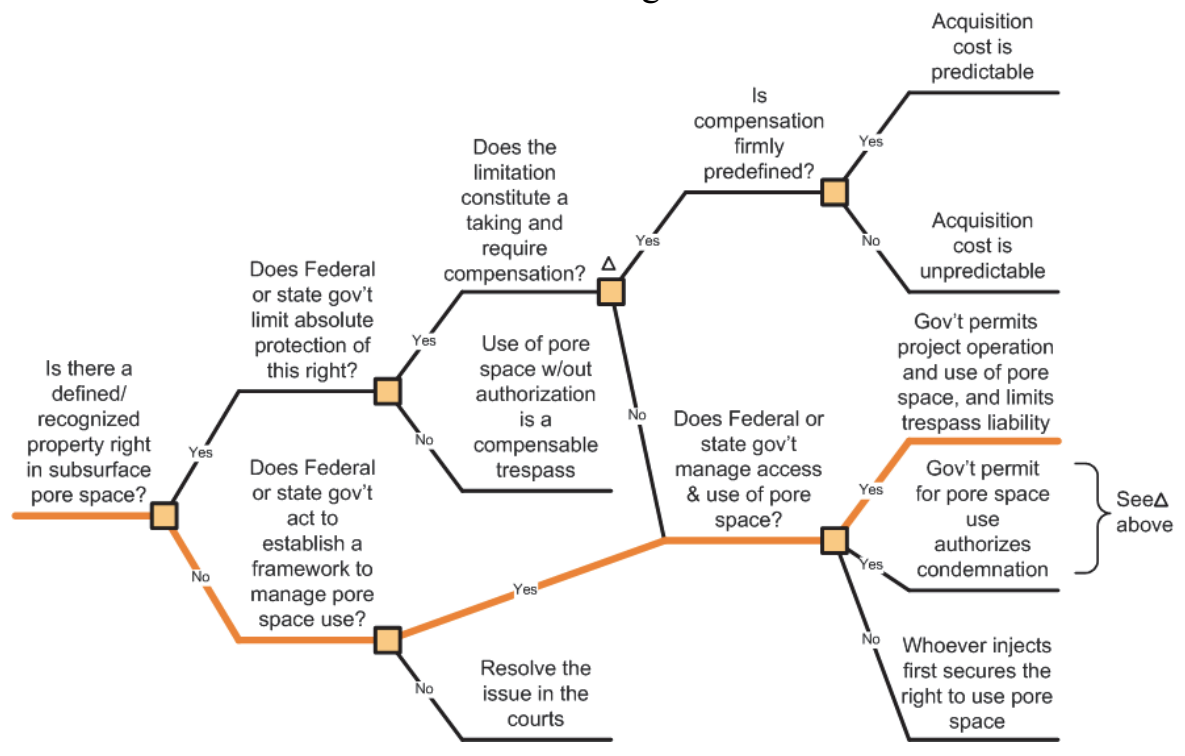

Figure 4: Federal or state ownership approach to managing access and use of pore space for geologic $\mathrm{CO}_{2}$ sequestration. ${ }^{394}$

3.4. Application of a Liability Rule-Limiting the Protection of Pore-Space Rights for Geologic $\mathrm{CO}_{2}$ Sequestration Based on Existing Uses and NonSpeculative, Investment-Backed Expectations

While vesting deep subsurface property in the federal or state governments has appeal as a means to facilitate new technologies like GCS, such an approach fails to recognize the realities of how the subsurface has historically been used and is used today. In many regions of the country, subsurface property rights below 300 meters (1,000 feet) include coal production, oil and natural gas exploration, production, and storage, freshwater production and storage, fluid waste and wastewater injection, and compressed air energy storage. Congress has chosen to implicitly recognize subsurface 
property rights under some circumstances, such as through the eminent domain provisions of the Natural Gas Act, ${ }^{395}$ and courts have recognized those rights by allowing for claims of trespass and nuisance in cases of actual interference or harm. ${ }^{396}$ Courts also have created mechanisms to compute just compensation when subsurface areas are needed for a public use such as natural gas storage. ${ }^{397}$ Thus, the country's history of the use of the subsurface is in fact different from its use of the airspace.

Even though common law limits property rights in airspace other than those used in connection with the surface, the same is far less true with regard to the subsurface. To date, there has been no federal declaration of a "public highway" in the subsurface, and any future declaration along those lines would come into conflict with vested economic interests in the subsurface in many areas of the country. Economic use of the subsurface may end at a certain depth, for instance any deeper than is necessary for existing and future natural gas storage, waste injection, and oil and gas development, but this depth is subject to changing technology and economics. And to the extent that $\mathrm{CO}_{2}$ sequestration will be at depths that are currently subject to existing or nonspeculative, investment-backed uses (and it appears that it will be), there do not appear to be any background principles of common law that would prevent state legislatures from vesting those property rights in surface owners or perhaps in mineral owners if they choose to do so - at least where the courts have not previously determined ownership - or prevent courts from limiting those rights or from recognizing contrary rights in the exercise of their jurisdiction.

An approach based on existing and non-speculative, investment-backed uses would likely result in the protection of subsurface property rights in some circumstances but not in others, based on whether the geology is suitable for $\mathrm{CO}_{2}$ sequestration, as well as whether sequestration might compete with oil and gas development, natural gas storage, and the like. Protecting subsurface property rights based on existing uses and non-speculative, investment-backed expectations would provide a middle-ground approach to property rights that makes geologic $\mathrm{CO}_{2}$ sequestration somewhat more expensive to implement, but would recognize, value, and compensate for competing economic uses that would be impaired by GCS and, consequently, lessen opposition to such projects. Moreover, this approach is firmly grounded in common law. In the

395. See 15 U.S.C. $§ 717 f(h)$.

396. See supra Section 2.

397. See Columbia Gas Transmission Corp. v. Exclusive Natural Gas Storage Easement, 962 F.2d 1192, 1199 (6th Cir. 1992). 
context of enhanced recovery of oil and gas, fluid waste injection, and freshwater storage and recovery, the courts have refused any absolute protection of property rights in the deep subsurface but have retained limited protection of property rights that would allow property owners to recover monetary compensation for damage to property caused by actual and substantial harm or interference. Allowing recovery only for actual damage to property is different from finding that a landowner possesses the type of property right in the subsurface that empowers the landowner to prevent others from injecting fluids into the pore space underlying the landowner's property (i.e., a property rule); it is this type of absolute protection of subsurface property rights the courts seem to have clearly rejected in the context of enhanced hydrocarbon recovery, underground fluid waste injection, and freshwater storage.

One application of this standard, shown in Figure 4, is in essence a "firstin-time, first-in-right" approach to the use of pore space for $\mathrm{CO}_{2}$ sequestration, where neither the government nor its agencies would oversee and manage the right to access and use subsurface pore space for $\mathrm{CO}_{2}$ sequestration. The "first in time, first in right" theory, also referred to as prior appropriation, has been used in the United States to encourage and give a legal framework for other commercial activities. Prior appropriation water rights, sometimes known as the Colorado Doctrine in reference to the U.S. Supreme Court case Wyoming v. Colorado, ${ }^{398}$ is a system of allocating water rights based on the general principle that water rights are unconnected to land ownership, and can be sold or mortgaged like other property. The first person to use a quantity of water from a water source for a beneficial use has the right to continue to use that quantity of water for that purpose. Subsequent users can use the remaining water for their own beneficial purposes provided they do not impinge on the rights of previous users. The early prospectors and miners in the California Gold Rush of 1849, and later gold and silver rushes in the western United States, also applied "first in time, first in right" theory to mineral deposits. The first one to discover and begin mining a deposit was acknowledged to have a legal right to mine. As with water rights, mining rights could be forfeited by nonuse. The miner's codes were later legalized by the federal government in Mining Act of 1866, and then in the Mining Law of 1872. Similarly, the Homestead Act of 1862 granted legal title to the first farmer to put public land into agricultural production. 


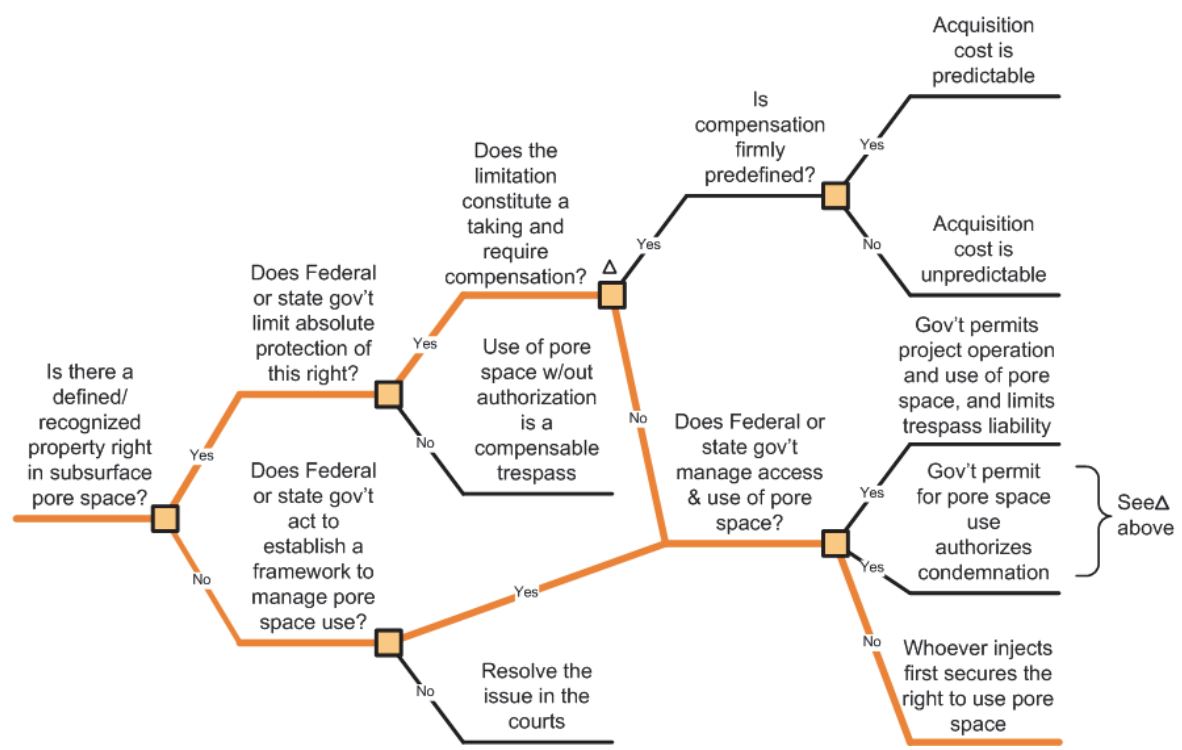

Figure 5: "First-in-time, first-in-right" approach to managing access and use of pore space for geologic $\mathrm{CO}_{2}$ sequestration. ${ }^{399}$

Under this approach, a GCS operator would possess the privilege to inject $\mathrm{CO}_{2}$ into subsurface pore space with the knowledge that it will migrate through the targeted geologic strata provided it is in compliance with regulations covering injection operations. Of course, the uncompensated use of pore space would only be permissible if it does not interfere with a verified existing or non-speculative, investment-backed use of the subsurface that has been asserted by a property owner-i.e., a liability rule, which is the rule that governs the use of pore space for underground disposal of fluid wastes.

A second, and our recommended, application of this standard would be for federal or state governments to codify a formal process for managing the access and use of pore space for geologic $\mathrm{CO}_{2}$ sequestration, wherein the project developer acquires a permit to use the pore space for GCS from the appropriate UIC permitting agency (see Figure 5). In certain cases, it might be necessary for the GCS project developer to acquire a more robust property interest, such as a sequestration easement, to assure that the integrity of the sequestration field is not compromised. In such cases, the grant of a permit to use pore space should also convey the right to invoke eminent domain. For 
such an approach to pass constitutional muster, legislation or the courts must specifically authorize the injection of $\mathrm{CO}_{2}$ for the purpose of permanent sequestration into designated underground geologic reservoirs and declare that GCS for the purpose of mitigating climate change is a public use carried out in the public interest. Additionally, courts must authorize, or legislation governing GCS must include provisions authorizing, UIC permitting agencies to issue permits granting GCS developers the right to access and use pore space for the injection and sequestration of $\mathrm{CO}_{2}$.

Common or statutory law should also create a presumption that the regulatory grant of the right to access and use pore space for geologic $\mathrm{CO}_{2}$ sequestration does not amount to a compensable taking because the issuance of a permit to use pore space (1) does not effect a confiscation of property and (2) is not the first step in a regulatory taking since pore-space owners will unlikely suffer either an actual loss or an interference with any investmentbacked expectation. However, the framework for managing the access and use of pore space for GCS should provide property owners with an opportunity to rebut this presumption by presenting evidence in an administrative permitting proceeding that demonstrates that $\mathrm{CO}_{2}$ sequestration will result in a material impairment to a current or non-speculative, investment-backed future use of the subsurface and that the property owner will suffer a consequent economic loss requiring just compensation. If it is demonstrated that a preexisting interest would be materially impaired by $\mathrm{CO}_{2}$ injection, then the geologic $\mathrm{CO}_{2}$ sequestration project should be permitted only upon (1) a modification of the project that avoids the impairment; (2) a contractual agreement between the owner of the preexisting interest and the project developer; or (3) a finding by the permitting agency that the condemnation of the preexisting interest through the exercise of eminent domain, with appropriate compensation, is necessary for the proper operation of the GCS project. Lastly, legislatures or the courts should establish subsurface trespass and nuisance liability standards whereby the use of pore space for the permanent geologic sequestration of $\mathrm{CO}_{2}$ by a valid permit holder is not compensable unless the owner of the pore space or other affected property owners suffer actual and substantial damages. 


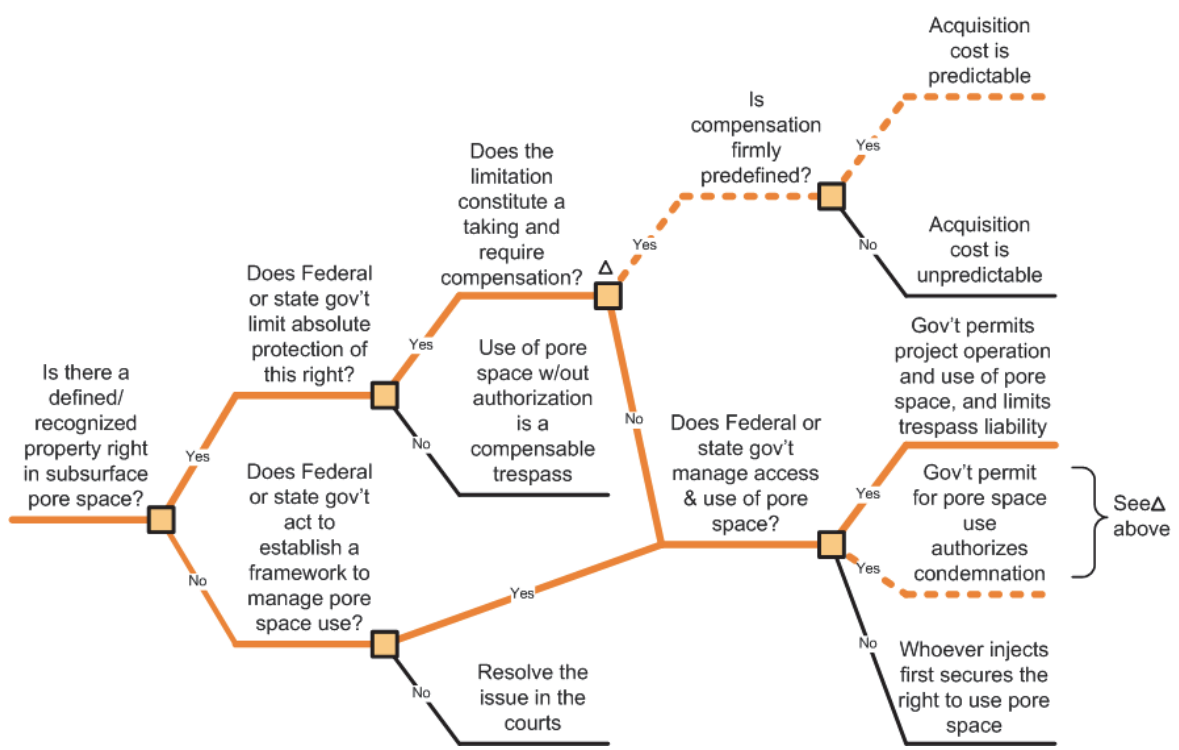

Figure 6: Recommended approach to managing access and use of pore space for geologic $\mathrm{CO}_{2}$ sequestration. ${ }^{400}$

\section{CONCLUSION}

If lawmakers commit to the widespread deployment of GCS, then project developers will need authorization to access and use subsurface pore space to avoid liability for subsurface trespass and nuisance. This could involve protracted negotiations with hundreds, if not thousands, of individual property owners for each GCS project sought to be developed; it could also be as straight forward as receiving the appropriate regulatory approval to inject $\mathrm{CO}_{2}$ for the purpose of permanent geologic $\mathrm{CO}_{2}$ sequestration. The case law arising from industrial and commercial underground fluid injection operations is instructive of how subsurface property rights might be dealt with in the context of GCS. As is thoroughly discussed in Section 2, this body of case law demonstrates that courts have consistently held certain underground fluid injection activities - e.g., enhanced hydrocarbon recovery, underground waste disposal, and groundwater storage and recharge - to be in the public interest and thus shielded from claims of trespass when: (1) the operation is licensed under a state or federal regulatory program and (2) the property owner could 
not demonstrate actual harm to, or interference with use and enjoyment of, the land as a result of injection and migration of fluids. In this line of cases, courts can be seen as having adhered to a liability rule, not a property rule, when deciding subsurface trespass and nuisance disputes. Whether legislatures or the courts will apply a liability rule to geologic $\mathrm{CO}_{2}$ sequestration remains an open and oft-debated question. Revising the Restatement of Torts such that it includes an exception for deep subsurface intrusions similar to those recognized for aircraft would help resolve this debate and, most importantly, reflect the prevailing judicial trend.

The legal complexity associated with acquiring pore-space rights for GCS may be further exacerbated by the fact that subsurface $\mathrm{CO}_{2}$ plumes could be very large in size — on the order of hundreds of thousands of square-kilometers in areal extent. By targeting sequestration formations that are favorable to limiting $\mathrm{CO}_{2}$ plume migration-e.g., thick formations with high porosity-property rights acquisition costs, regardless of whether the use of pore space for GCS is subject to a liability or property rule, may be considerably constrained. On the other hand, the use of thin formations for GCS with low porosities will likely lead to large $\mathrm{CO}_{2}$ plumes and high property rights acquisition costs, which in certain instances could render a project uneconomical, especially under a property rule. Moreover, to the extent GCS projects are developed and operated in areas where the subsurface is already being used commercially for natural gas storage, enhanced oil and gas production, hydraulic fracturing, or other uses, the cost of obtaining the rights to use pore space could be substantial. In situations where a GCS project comes into conflict with competing uses of the subsurface, the value of the right to use pore space for sequestration will be derived from the value of those rights as a function of the existing or future, investment-backed uses of the subsurface that would be precluded by GCS. In those circumstances where the geologic formation is appropriate for GCS but not for other commercial uses, the cost associated with acquiring the rights to use pore space might be nominal, or perhaps even zero, because no economic use would be precluded or impaired. Therefore, careful site selection is paramount from both a legal and economic perspective.

To be sure, the application of a property rule to geologic $\mathrm{CO}_{2}$ sequestration may very well foster public acceptance and appease staunch advocates of private-property rights. However, there is no demonstrable legal or economic rationale for requiring compensation to property owners who have no current or non-speculative, investment-backed future use of the subsurface where pore space is targeted for GCS. We believe that the application of a liability rule to GCS would be a pragmatic approach to 
mitigating the potential legal hurdles and negative economic effects associated with acquiring pore-space rights for $\mathrm{CO}_{2}$ sequestration. As discussed above in Section 3.4 , this would require the federal or state governments to codify a formal process for managing the access and use of pore space for geologic $\mathrm{CO}_{2}$ sequestration. Under such a framework, the project developer would apply for a permit to use the pore space for GCS, as well as the right to invoke eminent domain in those specific instances where condemnation of the pore space is necessary to protect the integrity of the sequestration field. Furthermore, the use of pore space for the permanent geologic sequestration of $\mathrm{CO}_{2}$ by a valid permit holder would not compensable unless the injection and migration of $\mathrm{CO}_{2}$ materially impairs current or non-speculative investment-backed future uses of the subsurface. This particular approach could facilitate the rapid development of commercial-scale GCS in response to climate change by both standardizing a procedure for acquiring pore space and constraining acquisition costs. 